\title{
Breeding and age-structure seasonality in Carollia brevicauda and other frugivorous bats (Phyllostomidae) in cloud forests in the Venezuelan Andes
}

Jesús Molinari ${ }^{* *}$ and Pascual J. Soriano ${ }^{1}$

\section{Abstract}

The most universal adaptations of tropical frugivores to the seasonal rhythms of fruiting involve their annual breeding cycles. In bats, these cycles typically follow a pattern termed bimodal polyestry, consisting in the production of one offspring per female twice during the breeding season. We use data gathered along 29 years to show that, in cloud forests in the Venezuelan Andes, the breeding cycles of Carollia brevicauda and other frugivorous phyllostomid bats (eigth species of the genera Sturnira, Artibeus, Dermanura, Enchisthenes, and Platyrrhinus) conform to bimodal polyestry, with a high interspecific synchronization and a low interannual variability. We analyze the adaptive significance of this pattern in terms of three hypothetical variables: demand, consumption, and supply of food sources, explicitly concluding that the seasonality of fruit production, resulting from the average rainfall regime, is the ultimate factor causing bimodal polyestry. The constancy in the seasonal schedule of breeding and concomitant fluctuation of age proportions, both in the bat populations studied under natural conditions, and in captive Carollia colonies maintained under yearround uniform conditions, suggests presence of an endogenous component in the annual breeding cycles of frugivorous phyllostomids. To conclude, we argue that the seasonality of fruiting is also likely to be the proximate environmental factor modulating these cycles, irrespective of whether it does so indirectly as a time cue entraining endogenous rhythms, or directly as a limiting factor determining whether bat breeding and population growth are possible.

Key words: Artibeus, bimodal polyestry, circannual rhythms, Dermanura, Enchisthenes, environmental cues, Platyrrhinus, reproductive strategies, Sturnira, tropical seasons.

\section{Resumen}

Las adaptaciones más universales de los frugívoros tropicales a los ritmos estacionales de fructificación atañen a sus ciclos anuales de cría. En murciélagos, estos ciclos típicamente se ajustan a un patrón denominado poliestría bimodal, consistente en la producción de un descendiente por hembra dos veces durante la estación de cría. Empleamos datos reunidos durante 29 años para documentar que, en selvas nubladas de los Andes Venezolanos, los ciclos de cría de Carollia brevicauda y otros murciélagos filostómidos frugívoros (ocho

'Universidad de Los Andes. Facultad de Ciencias. Departamento de Biología. Mérida 5101. Venezuela. E-mail: molinari@ ula.ve (JM), pascual@ula.ve (PJS)

*Corresponding author 
especies de los géneros Sturnira, Artibeus, Dermanura, Enchisthenes y Platyrrhinus) concuerdan con la poliestría bimodal, con elevada sincronía interespecífica y baja variabilidad interanual. Analizamos el significado adaptativo de este patrón en términos de tres variables hipotéticas: demanda, consumo y suministro de recursos, concluyendo explícitamente que la estacionalidad de la fructificación, resultante del régimen promedio de precipitaciones, es el factor selectivo último causante de la poliestría bimodal. La constancia en la estacionalidad de la cría y concomitante fluctuación de proporciones etarias, tanto en las poblaciones de murciélagos estudiadas bajo condiciones naturales, como en colonias cautivas de Carollia mantenidas bajo condiciones uniformes todo el año, sugiere presencia de un componente endógeno en los ciclos de cría de los filostómidos frugívoros. Para concluir, argumentamos que la estacionalidad de la fructificación probablemente también es el factor próximo ambiental modulador de estos ciclos, independientemente si lo hace indirectamente como factor sincronizador de ritmos endógenos, o directamente como un factor limitante que determina si la actividad de cría y el crecimiento poblacional de los murciélagos son posibles.

Palabras clave: Artibeus, Dermanura, Enchisthenes, estaciones tropicales, estímulos ambientales, estrategias reproductivas, Platyrrhinus, poliestría bimodal, ritmos circanuales, Sturnira.

In tropical forests, the availability of ripe fruit to frugivorous vertebrates is often concentrated Introduction between the middle of the dry season and the first half or first two-thirds of the wet season (Medway 1972; Frankie et al. 1974; Croat 1975; Hilty 1980; Opler et al. 1980; Alexandre 1980; Jackson 1981; Lieberman 1982; Terborgh 1983; Gautier-Hion et al. 1985; Schaik 1986; Koptur et al. 1988; Heideman 1989a; Peres 1994; Estrada and Coates-Estrada 2001; Haugaasen and Peres 2005; Bentos et al. 2008). To cope with the resulting shortage of fruit during the late wet season and early dry season, frugivores resort to strategies such as: 1) subsisting on stored food or body fat and protein accumulated during the previous time of plenty (McNab 1976; Smythe 1978, 1986; Emmons 1980; Smythe et al. 1982; Goldizen et al. 1988); 2) increasing foraging time (Leck 1972; Terborgh 1983); 3) living on alternate foods, such as unripe or less-preferred fruit, foliage, and nectar and pollen (Heithaus et al. 1975; Foster 1977; Janson et al. 1981; Smythe et al. 1982; Leighton and Leighton 1983; Terborgh 1983; Feer 1989; Peres 1994); 4) modifying home ranges to increase the chance of encountering fruit (Fleming and Heithaus 1986; Leighton and Leighton 1983); or 5) migrating to other localities in which fruit is more abundant (Nelson 1965; Morton 1977; Marshall and McWilliam 1982; Worthington 1982; Thomas 1983; Wheelwright 1983; Richter and Cumming 2006). However, the most universal adaptations of tropical frugivores to the alternation of seasons of plenty and shortage of fruit concern their annual breeding cycles (Molinari 1993).

The annual breeding cycles of Neotropical frugivorous bats have been studied in southern Mexico and Central America (Fleming 1971; Fleming et al. 1972; LaVal and Fitch 1977; Bonaccorso 1979; Dinerstein 1986; Wilson et al. 1991; Estrada and Coates-Estrada 2001; Stoner 2001; Chaverri and Kunz 2006; Montiel et al. 2011; Durant et al. 2013), and in some areas of South America (Taddei 1976; Thomas 1983; Willig 1985; Graham 1987; Bonilla 
and Turriago 1988; Cosson and Pascal 1994; Sosa and Ramoni-Perazzi 1995; Bernard 2002; Mello and Fernandez 2000; Mena and Williams de Castro 2002; Mello et al. 2004, 2009; Duarte and Talamoni 2010). Wilson (1979) and Racey (1982) provided syntheses of earlier literature. These authors noted that, with few exceptions, breeding in these bats follows a pattern known as bimodal polyestry (Wilson 1973), consisting in the production of two offspring per female, each at a different parturition, during a breeding season beginning late in the dry season and ending toward the mid or late wet season. At tropical latitudes, the same pattern also appears to be the rule among Paleotropical frugivorous bats (Okia 1974a, b, 1987; Mutere 1968; Baranga 1980; Marshall and McWilliam 1982; Thomas and Marshall 1984; Bernard and Cumming 1997; Kofron 1997; Heideman and Powell 1998; Bumrungsri et al. 2007; Monadjem and Reside 2012), which are not closely related to their Neotropical counterparts and most likely evolved frugivory independently (Wible and Novacek 1988; Hutcheon et al. 2002). Both in Neotropical and Paleotropical frugivorous bats, seasonal monoestry or aseasonal polyestry are the known exceptions to bimodal polyestry (Mutere 1967; Fayenuwo and Halstead 1974; Wilson 1979; Heideman 1988; Penzhorn and Rautenbach 1988; Estrada and Coates-Estrada 2001; Stoner 2001; Haldar and Yadav 2006; Kofron 2007a, b; Duarte and Talamoni 2010; Montiel et al. 2011). In Neotropical frugivorous bats, seasonal monoestry has been observed in northwestern Costa Rica (Artibeus jamaicensis, Carollia perspicillata; Stoner 2001) and in the Brazilian Atlantic forest (Artibeus lituratus; Duarte and Talamoni 2010), whereas aseasonal polyestry has been observed in southern Mexico (A. jamaicensis, Carollia brevicauda, Sturnira lilium; Estrada and Coates-Estrada 2001; Montiel et al. 2011). Equivalent adaptive strategies, involving breeding cycles in nonflying mammals (e. g. Harrison 1955; Fleming 1973; CharlesDominique 1977; Heany and Thorington 1978; O'Connell 1979; Charles-Dominique et al. 1981; Glanz et al. 1982; Smythe et al. 1982; Gliwicz 1984; Goldizen et al. 1988; Snowdon and Soini 1988; Cerqueira et al. 1989; Roosmalen and Klein 1988; Carnegie et al. 2011; Heesen et al. 2013), and breeding and molting cycles in birds (Moreau 1937; Skutch 1950; Snow 1976; Foster 1975; Worthington 1982), are also found in other frugivorous vertebrates of tropical forests.

Even though there is general agreement that seasonal fluctuations in fruit availability, resulting from the seasonality of rainfall, is the ultimate factor, or selective force, that has shaped the breeding patterns of frugivorous vertebrates in the tropics, the nature of the proximate factors, or mechanistic cause, responsible for the onset and synchrony of each annual cycle remains contentious. For frugivorous birds, some authors (Ward 1969; Fogden 1972; Jones and Ward 1976; Snow 1976; Worthington 1982) have argued the proximate and the ultimate factors to be the same (i. e. seasonal fluctuations in the availability of fruit). In the Neotropics, climatic factors, namely rainfall or temperature, have been suggested as possible proximate factors for frugivorous bats and nonflying mammals (Fleming et al. 1972; Glanz et al. 1982; Willig 1985; Mello et al. 2004, 2009). Resource abundance has been proposed as the proximate factor for Haplonycteris fischeri, a Paleotropical frugivorous bat (Heideman 1988).

In this study, we report data recorded along 29 years on the annual cycles of breeding and age structure in Carollia brevicauda (Phyllostomidae) and eight other species of frugivorous phyllostomids of the genera Sturnira, Artibeus, Dermanura, Enchisthenes, and Platyrrhinus. Based on these data and on a review of previously published information, 
we examine the ultimate and proximate factors of annual breeding cycles in frugivorous phyllostomids.

Study area. Main study areas were on the southeast slope of the Sierra de La Culata, near the city of Mérida, Mérida state, Venezuela. The natural vegetation of the areas is cloud forest, which still occupies a large fraction of slopes at elevations of 1,900 - 2,900 m. This cloud forest is diversified into two major kinds differing in floristic composition and vertical structure: lower montane cloud forest below 2,200 m, and higher montane cloud forest above 2,200 m (Ataroff and Sarmiento 2003). Most bats in our sample were captured in cloud forests at four sites: Monte Zerpa $\left(8^{\circ} 38^{\prime} \mathrm{N},-71^{\circ} 10^{\prime} \mathrm{W}\right)$, elevations 2040 - $2100 \mathrm{~m}$; Vega de Don Pedro and Monterrey $\left(8^{\circ} 41^{\prime} \mathrm{N},-71^{\circ} 07^{\prime} \mathrm{W}\right)$, elevations 2.330 - $2370 \mathrm{~m}$; and Prado Verde $\left(8^{\circ} 40^{\prime} \mathrm{N},-71^{\circ} 06^{\prime} \mathrm{W}\right)$, elevation $2,200 \mathrm{~m}$. A small fraction of the bats in our sample were captured in cloud forests at three additional sites: La Mucuy Alta $\left(8^{\circ} 38^{\prime} \mathrm{N},-71^{\circ}\right.$ $02^{\prime} \mathrm{W}$ ), elevation $2260 \mathrm{~m}$; La Pedregosa Alta $\left(8^{\circ} 37^{\prime} \mathrm{N},-71^{\circ} 11^{\prime} \mathrm{W}\right)$, elevation $2000 \mathrm{~m}$; and near Jají ( $8^{\circ} 34^{\prime} \mathrm{N},-71^{\circ} 19^{\prime} \mathrm{W}$ ), elevation 1,950 m.

Climate data for 27 years (1974 - 2001) are available for the Santa Rosa Meteorological Station (Fig. 1), which is adjacent $\left(8^{\circ} 37^{\prime} 39^{\prime \prime} \mathrm{N},-71^{\circ} 09^{\prime} 25^{\prime \prime} \mathrm{W}\right.$, elevation 1,950 m) to Monte Zerpa, one of the mist-netting sites. Average yearly temperature is $17.2^{\circ} \mathrm{C}$. Average monthly temperatures range from minima of $16.0-16.3^{\circ} \mathrm{C}$ in December and January, to maxima of $17.8-18.0^{\circ} \mathrm{C}$ in May, August, and September (Fig. 1). Though the overall annual temperature pattern is bimodal, monthly variability is proportionally high, to the point that the pattern changes substantially from year to year.

The average rainfall pattern is also bimodal, and thus four seasons can be recognized (Fig. 1), to which hereafter we will refer to as the "long dry season" (December-March), "first wet season" (April-June), "short dry season" (July), and "second wet season" (AugustNovember). Monthly variability in rainfall is substantial, thus such seasons can become barely or not distinguishable in particular years (Fig. 1).

During 1982 and 1983, which were the years in which we sampled bat populations most intensively, and 1981, a year possibly causing time-lag effects on bat reproduction in 1982 and 1983 (Fig. 2), monthly rainfall in the Santa Rosa Meteorological Station deviated considerably from the average annual pattern (Fig. 1): the four-seasons pattern was not clearly discernible in 1981, the short dry season of 1982 was much more severe than the preceding (1981 - 1982) long dry season, the long dry season of 1982 - 1983 was unusually severe and, conversely, the wet seasons were easily recognizable only in 1982, and 1983 (Fig. 2).

Assuming that rainfall/humidity could act as an environmental cue synchronizing the annual breeding cycle of small mammals, such as Neotropical frugivorous bats (Fleming et al. 1972; Glanz et al. 1982; Willig 1985), the time scale of physiological relevance would likely be much shorter than a monthly one. Therefore, we also grouped the 1981, 1982, and 1983 rainfall data for the Santa Rosa Meteorological Station into semimonthly and weekly intervals (Fig. 2). Shortening of the time scale makes the seasonal pattern of wet and dry seasons much less evident: only the first wet and short dry seasons of 1982, and the long dry season of 1982-1983, remain distinguishable at a weekly scale (Fig. 2). 


\section{Materials}

Field work. From September 1979 through January 2007, we mist-netted across trails within cloud forest used by bats as flyways. From October 1981 through March 1984, we also mistand hand-netted in roosts used as diurnal retreats by Carollia brevicauda. This increased sample size for this species, and allowed obtaining data on non-volant infant bats of the species. Immediately after capture, we placed each bat individually in a cloth bag, in which we held it for 30 - 60 min before processing to make certain that any food remains present in its digestive tract would be defecated prior to data taking and subsequent release. We bandmarked a large fraction of released bats either by making a small incision in the propatagium and slipping a lipped aluminum band through it and around the forearm, or by means of a plastic necklace carrying a numbered aluminum band (Bonaccorso et al. 1976; Gannon 1994).

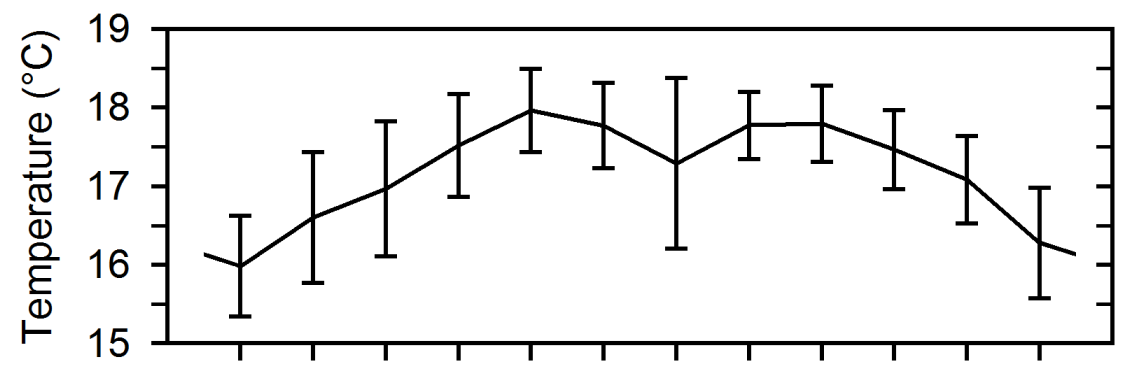

Fig. 1. Average monthly temperature and rainfall in the Santa Rosa Meteorological Station, Estado Mérida, Venezuela. Vertical bars represent \pm 1 standard deviation.

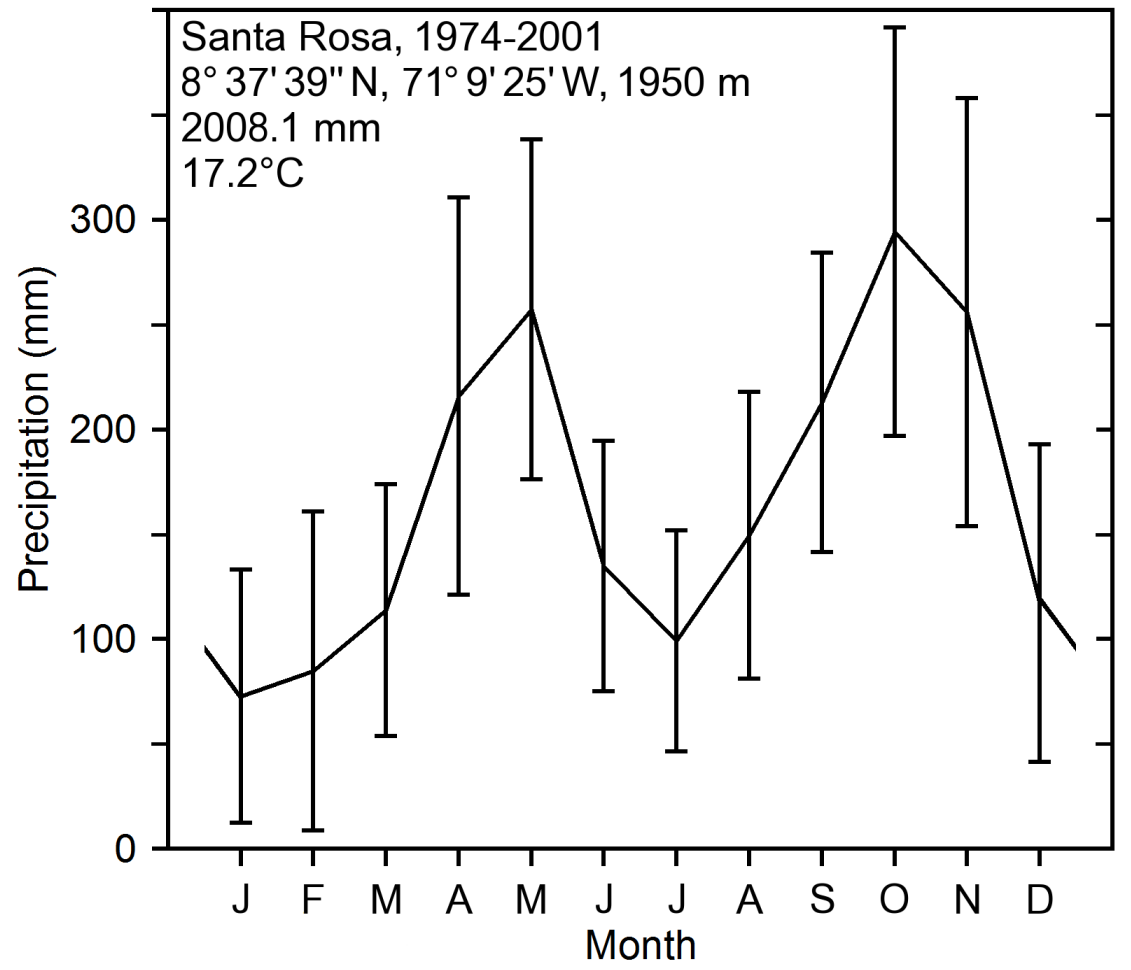

Employing a standard data sheet, we recorded at least the following data from each captured bat: identification number, date and site of capture, species, sex, breeding status, age parameters (dentition, pelage, finger epiphyses), body mass, and forearm length. We assessed breeding status in females by observing the condition of mammae (minute and hidden in pelage, naked and milkless, with milk) and noting if pregnancy was externally 
evident. Breeding categories of individuals recognized on the basis of these criteria are presented in Results. We classed dentitions as deciduous, mixed, or permanent; and pelages as juvenile, intermediate, or adult. To determine the stage of ossification of the metacarpal and phalangeal epiphyses, the wings of each bat were transilluminated with a handheld flashlight. Individual bats were noted as having one of three stages of ossification:stage 1, implying entirely nonossified (cartilaginous) epiphyses; stage 2, in which the epiphyses are only partly cartilaginous owing to a distal center of ossification being present; and stage 3, implying entirely ossified epiphyses. These same stages were distinguished and carefully illustrated by Kunz and Anthony (1982). We also palpated epiphyses to supplement observations on transilluminated wings. Epiphyseal regions felt evenly tapered and protuberant in bats with ossification of stage 1, compact and angular in bats with ossification of stage 3, and intermediate in bats with ossification of stage 2. Age classes recognized on the basis of these criteria are presented in Results. For C. brevicauda, we estimated the approximate range of ages for each age class by employing recapture records of individuals for which an approximate date of birth was known or could be estimated.
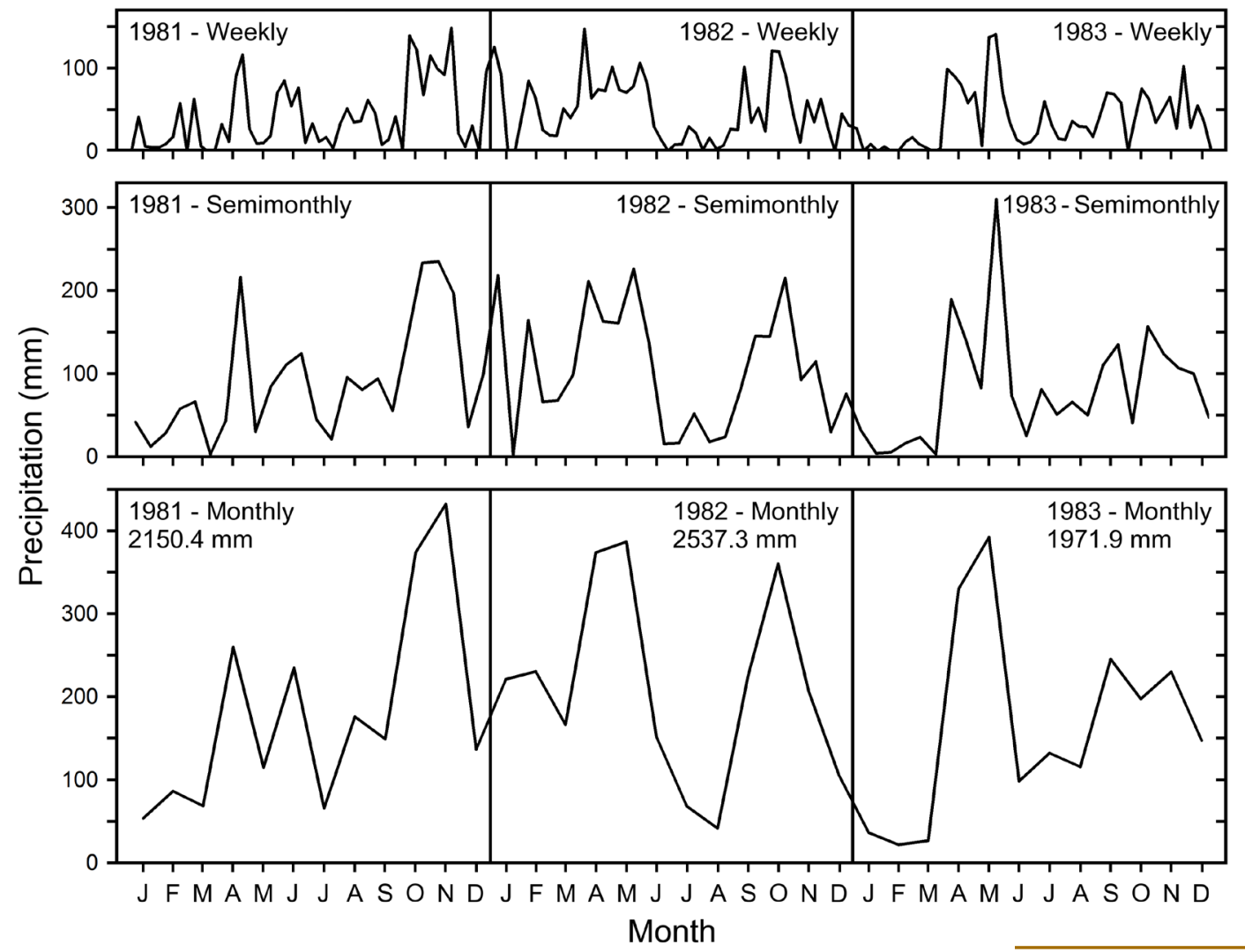

Fig. 2. Monthly, semimonthly, and weekly rainfall during 1981, 1982, and 1983 in the Santa Rosa Meteorological Station, Estado Mérida, Venezuela.

Data analyses. Based on field data, each adult female was assigned to one of seven breeding categories: 1) no external signals of pregnancy + no indication of present or past lactating activity; 2) pregnant (medium pregnancy); 3) pregnant (advanced pregnancy); 4) lactating; 5) postlactating; 6) pregnant (medium pregnancy) + lactating; 7) pregnant (medium pregnancy) + postlactating. Similarly, each bat of any sex was assigned to one of four age categories: 1) adult; 2) subadult; 3) juvenile; 4) infant. Ranges of body masses and measurements, discrete characters, and absolute age estimations of individuals of Carollia brevicauda belonging to these breeding and age categories are reported in Results. 
For each of the nine bat species, we grouped data regardless of year of collection (1979 - 2007) in 1.5-month intervals (Fig. 3, Table A1). This procedure led to what we feel is the minimum number of intervals (8) needed to portray with sufficient detail the temporal succession of breeding and age-structure categories. Only in the case of $C$. brevicauda, sample sizes were large enough for subdividing data (maintaining the same 1.5-month intervals) to allow statistical comparisons involving different years, or groups of years. Therefore, for this species we had four data sets: 1) all years combined (1979 - 2007); 2) multiyear (1979 - 2007, excluding 1982 and 1983); 3) single year 1 (1982); and 4) single year 2 (1983). In the case of other species, smaller sample sizes required a different procedure, namely lumping data to allow statistical comparisons among monophyletic supraspecific groups (clade names according to Wetterer et al. 2000), as follows: Sturnirini (Sturnira bidens + S. bogotensis + S. erythromos + S. ludovici); Stenodermatini (Artibeus lituratus + Dermanura bogotensis + Enchisthenes hartii + Platyrrhinus umbratus); Stenodermatinae (Sturnirini + Stenodermatini).

\begin{tabular}{|c|c|c|c|c|}
\hline \multirow{5}{*}{$\begin{array}{l}\text { Kolmogorov-Smirnov } \\
\text { 2-sample goodness-of- } \\
\text { fit tests (Z) comparing } \\
\text { distributions along } \\
1.5 \text {-month intervals of } \\
\text { individuals belonging to } \\
\text { each female-breeding or } \\
\text { age category. }\end{array}$} & Data sets compared (Carollia vs. Stenodermatinae) & Cells & Z & $\begin{array}{r}p \text {-value } \\
\text { (2-tailed)* }\end{array}$ \\
\hline & Pregnant females & 8 vs. 8 & 0.250 & 1.000 \\
\hline & Lactating females & 8 vs. 8 & 0.500 & $>0.964$ \\
\hline & Postlactating females & 8 vs. 8 & 0.750 & $>0.627$ \\
\hline & Adults & 8 vs. 8 & 0.500 & $>0.964$ \\
\hline \multirow{3}{*}{$\begin{array}{l}\text { *All } Z \text { values non- } \\
\text { significant. See Methods }\end{array}$} & Subadults & 8 vs. 8 & 0.500 & $>0.964$ \\
\hline & Juveniles & 8 vs. 8 & 0.500 & $>0.964$ \\
\hline & All above categories consecutively & 48 vs. 48 & 0.816 & $>0.518$ \\
\hline
\end{tabular}

For statistical tests, we used SPSS for Windows, version 11. We used the KolmogorovSmirnov 2-sample goodness-of-fit tests to compare, for C. brevicauda (1979-2007) versus the Stenodermatinae (1979-2007), the distributions along the 1.5-month intervals of individuals belonging to each female breeding category, and each age category (Table 1); $i$. e., we conducted a test separately for each female breeding category and each age category. These tests were aimed at detecting significant differences in the seasonal distribution of the proportions of female-breeding and age categories between both data sets. Before carrying out the tests, we equalized the size of the larger sample to the size of the smaller sample of the same 1.5-month interval without altering the proportional abundance of each female breeding or age category. For example, in the case of the 16 April-31 May interval, sample size for C. brevicauda $(n=149)$ was larger than sample size for the Stenodermatinae $(n=96)$. The ratio between these sample sizes is $96 / 149=$ 0.6443 . Therefore, we reduced the sample size of $C$. brevicauda for this interval to 96 by multiplying the numbers of adults (81), subadults (18), and juveniles (50) by 0.6443 , thus obtaining an "equalized" sample consisting of 52 adults, 12 subadults, and 32 juveniles. Once this was done, we used a test to compare the abundances of the adults along the eight intervals, another test to compare the abundances of the subadults along the eight intervals, and so on.

To gauge the intraspecific, interspecific, and interannual synchronization among the nine species of bats considered in the study with regard to the seasonal schedule of femalebreeding and age structure changes, we calculated Pearson $(r)$ and Spearman correlation 
$(\rho)$ coefficients, and their significances. Because Pearson and Spearman correlation coefficients were very similar in magnitude (as typical, Spearman values were a little lower) and significance, we report only Pearson coefficients (Table 2). We tested all possible non-redundant pairs involving C. brevicauda (1979 - 2007, multiyear, 1982, 1983) and supraspecific (Sturnirini, Stenodermatini, Stenodermatinae) data sets. In contrast with the previous procedure (Table 1), we considered together, as a single data row, all categories in each data set, i.e., we calculated correlations by considering simultaneously female (non breeding, pregnant without distinction between medium and advanced pregnancies, and lactating) and age (juveniles, subadults, and adults) categories, and by pairing proportions of such categories belonging to the same 1.5-month intervals of the two data sets (Table A1). To preclude variation in sample size from affecting correlations (Bates et al. 1996), we considered proportions of individuals in categories, as opposed to numbers of individuals in categories. In our case, there is no risk of spurious correlations owing to the use of proportions because transformations, whose only effect is to equalize samples to a common size $(n=100)$, do not involve shared divisors or multipliers that might act as confounding factors, or lurking variables, i.e., each sample was internally standardized with no influence of other samples. However, we note that correlation coefficients obtained using numbers instead of proportions of individuals are moderately lower and similarly significant to those that we report (Table 2). This can be verified by repeating our calculations using data supplied in the Appendix. Because we calculated the significances of multiple correlation coefficients, we applied the Bonferroni correction to them. This correction is the simplest and most conservative method to control the probability of obtaining false positives (at the expense of increasing the proportion of false negatives) as a result of testing numerous hypotheses (e. g. Curtin and Schulz 1998).

Female-breeding categories and age classes. We distinguish four female-breeding categories:

A) Non-breeding. Females that do not do not belong to the pregnant, lactating, or postlactating categories.

$B$ ) Pregnant. Operationally defined as females that show externally visible pregnancies. In Table A1, we subdivide this category into females with medium pregnancies, and females with advanced pregnancies.

C) Lactating. Females with mammae from which milk can be extruded. This category includes females lacking externally visible pregnancies and females with medium pregnancies, but excludes females with advanced pregnancies, which initiate colostrum or milk production shortly before parturition.

D) Postlactating. Females that have ceased to suckle their offspring recently. These females are recognizable for their milkless but naked and enlarged mammae. This category includes females lacking externally visible pregnancies and females with medium pregnancies.

Though we used only three of them in the analyses, we distinguish four age classes:

A) Infants. Having non-ossified epiphyses (stage 1, see Methods), juvenile pelage, totally or partially deciduous dentition, and no or limited flying capacity (thus they 
were captured only within a roost, or while being carried by the mother). In Carollia brevicauda, members of this age class are aged from 0 to approximately 25 days, have body masses ranging from 5.0 to $10.5 \mathrm{~g}$ (mean $=7.7, \mathrm{SD}=1.5, n=20$ ), and forearm lengths ranging from 26.9 to $37.2 \mathrm{~mm}$ (mean $=31.5, \mathrm{SD}=3.7, n=21)$.

$B$ ) Juveniles. Having non-ossified epiphyses (stage 1), and juvenile pelage. Differ from members of the previous age class in having complete permanent dentition and in being volant. In C. brevicauda, members of this age class are aged from slightly less than one month to approximately two months, have body mass ranging between 10.5 and $16.0 \mathrm{~g}$ (mean $=13.4, \mathrm{SD}=1.3, n=67)$, and forearm lengths ranging between 37.0 and $41.9 \mathrm{~mm}$ (mean $=40.1, \mathrm{SD}=1.0, n=66$ ).

C) Subadults. Differ from members of the previous age class in having partially ossified epiphyses (stage 2), and adult or close-to-adult pelage. In C. brevicauda, members of this age class are approximately aged two to three months, have body masses ranging from 14.0 to $20.0 \mathrm{~g}$ (mean $=16.2, \mathrm{SD}=1.1, n=91$ ), and forearm lengths ranging from 38.2 to $43.0 \mathrm{~mm}$ (mean $=40.7, \mathrm{SD}=0.5, n=86$ ).

$D$ ) Adults. Differ from members of the previous age class in having completely ossified epiphyses (stage 3), and, presumably, in being reproductively mature (referentially, females of the frugivorous phyllostomid, Dermanura watsoni, are known to reach sexual maturity when aged three to six months; Chaverri and Kunz 2006). In C. brevicauda, members of this age class are aged approximately four months or older, have body masses ranging from 15.0 to $21.5 \mathrm{~g}$ ( mean $=18.1, \mathrm{SD}=1.3, n=230$ ) in males, and from 15.0 to $21.0 \mathrm{~g}$ (mean $=17.7, \mathrm{SD}=1.5, n=273$ ) in females, and have forearm lengths ranging from 38.2 to $43.0 \mathrm{~mm}$ (mean $=40.6, \mathrm{SD}=0.9, n=225$ ) in males, and from 38.5 and $44.2 \mathrm{~mm}$ (mean $=40.9, \mathrm{SD}=1.0, n=339$ ) in females.

Breeding and age-structure seasonality. In the 15 January-28 February and 1 March-15 April intervals, corresponding to the last half of the long dry season and onset of the first wet season (Fig. 1), indications (lactating and postlactating females, juveniles, subadults) of the preceding annual breeding cycle have disappeared (Fig. 3, Table A1). Because females with medium pregnancies predominate during 15 January-28 February, and females with advanced pregnancies and lactating females predominate during 1 March -15 April, a well-synchronized start of a communal breeding season occurs, with a first annual birth-pulse beginning towards the onset of the first wet season.

As a consequence of a first annual birth-pulse having begun during the preceding interval, there is a substantial appearance of juveniles and subadults in the 16 April-31 May, 1 June 15-July, and 16 July-31 August intervals, which comprise the interlude from the first wet season through the beginning of the second wet season (Fig. 3, Table A1). As expected, juveniles predominate over subadults during 16 April-31 May, and subadults over juveniles thereafter. In contrast with the preceding interval of 1 March -15 April, females with medium pregnancies predominate over females with advanced pregnancies, indicating not only that the first annual birth-pulse is ending, but also that a second annual birth-pulse is either approaching or, as suggested by the presence of lactating females, initiating. The presence of simultaneously pregnant (medium pregnancies) and either lactating or postlactating females during the breeding season (Table A1) is additional evidence supporting the notion of a second annual birth-pulse 
per female, or bimodal polyestry. The second annual birth-pulse appears less marked and, especially, less synchronized than the first.

During the 1 September-15 October interval, corresponding to the second wet season, the persistence of juveniles and subadults reflects the second annual birth-pulse having been initiated in the preceding intervals. However, because during this interval pregnant females are few and lactating and especially postlactating females are abundant, and because subadults predominate over juveniles, we conclude that the second annual birth-pulse, and therefore the communal breeding season, is about to end.

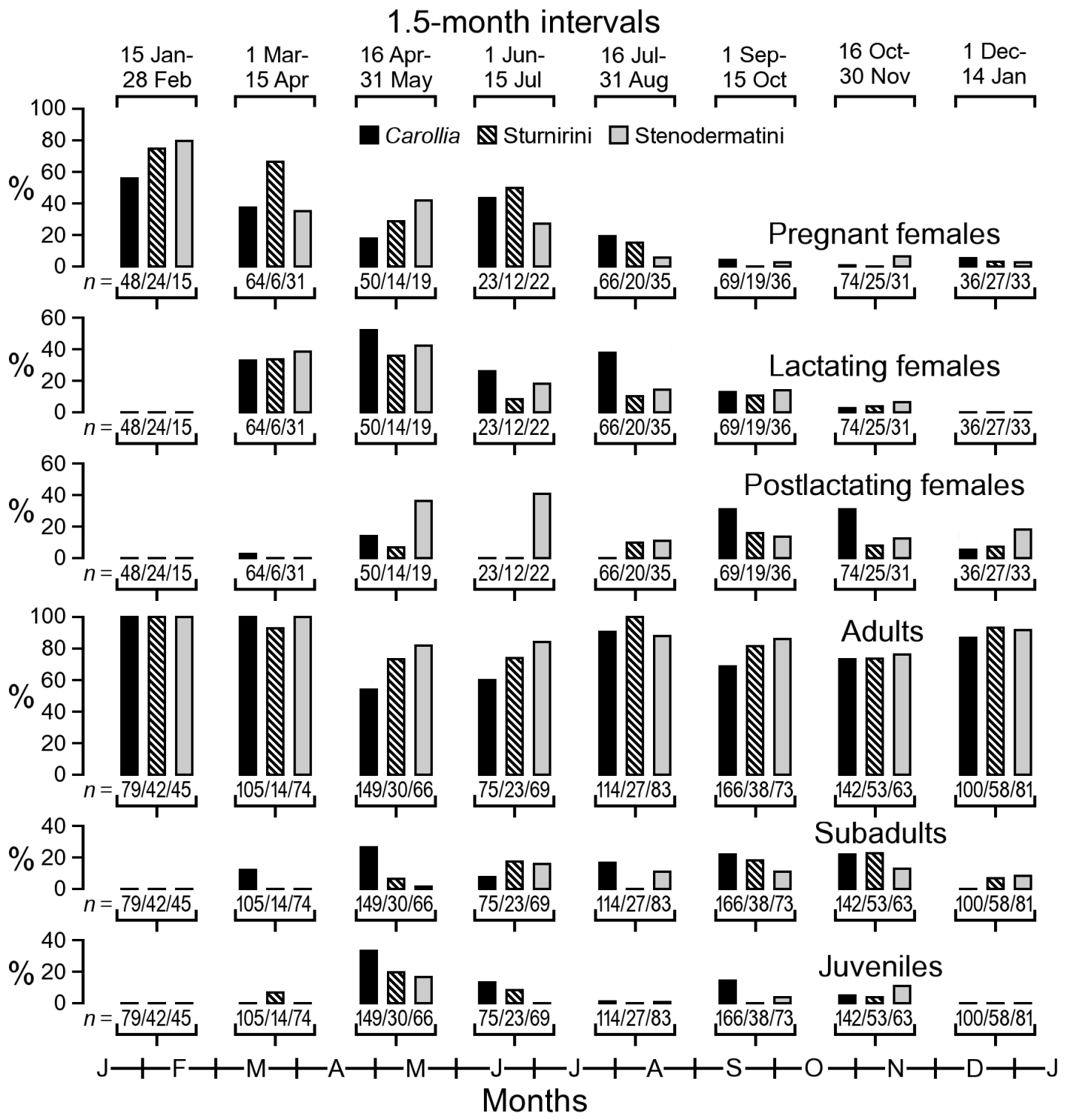

Fig. 3. Breeding (adult females) and age structure (both sexes) seasonality for one specific (Carollia brevicauda) and two supraspecific (Sturnirini, Stenodermatini) bat groups. Data were obtained from 1979 through 2007, and grouped in 1.5-month intervals. Sample sizes are indicated below diagrams. The correct position of diagrams in a continuous yearly scale is indicated by means of the centered vertical line below each horizontal bracket.

During the 1 December-14 January interval, corresponding to the initial half of the long dry season, non-breeding females and adults markedly predominate in the samples of all species (Table A1), making this the interval in which the intra and interspecific synchrony is most notable. Postlactating females and subadults are present, indicating that a birth-pulse occurred earlier. Nevertheless, no lactating females or juveniles were detected, indicating that the birth-pulse did not extend into the immediate past. Because pregnant females are few, and exhibit only medium pregnancies, it also appears that a birth-pulse is not to be 
expected in the immediate future (this is supported by the absence of lactating females and low proportion of females with advanced pregnancies during the following interval of 15 January-28 February). Therefore, there is a communal non-breeding phase coinciding with the latter part of the second wet season and onset of the long dry season.

In summary, pregnant females show two well-defined annual peaks of proportional abundance, a first one during the later part of the long dry season, and a second one coinciding with the short dry season. Lactating females show an equivalent but delayed pattern, with peaks approximately coinciding with the first wet season, and initial half of the second wet season. Postlactating females show two frequency peaks following those of lactating females. The two peaks in postlactating females are followed by peaks in the proportional abundance of juveniles, which coincide with the final half of the first wet season, and second wet season. Likewise, the proportional abundance of subadults shows peaks near and during the short dry season, and final half of the second wet season and beginning of the long dry season. Finally, adults show frequency fluctuations resulting from the appearance of young age classes, and attain their maximal proportional abundance in the middle of the long dry season as a consequence of the conclusion of the breeding season three to four months earlier. Therefore, although data for several species are insufficient during some intervals (Table A1), the overall trend shown by all species is clearly consistent with bimodal polyestry, with a high degree of intra and interspecific synchrony.

Statistical significance of the pattern. In a broad comparison of Carollia brevicauda with the Stenodermatinae as a whole, we could not find significant differences in the seasonal distribution of the frequencies of three female breeding and three age categories, either considered separately from other categories, or collectively (Table 1). Therefore, we could not detect differences (which could result from discrepant interannual variabilities, growth rates, lengths of gestation and lactation periods, or responses to environmental cycles) in the timing of the breeding season between C. brevicauda and the Stenodermatinae.

On the contrary, there is statistical support for the notion that all bat species considered in our study are reproductively synchronized (Table 2). In spite of ample differences from year to year in the quantity and seasonal distribution of rainfall (Figs. 1 and 2), we found very high and significant correlations between every possible pair of non-redundant data sets involving different bat species and year combinations (Table 2). Therefore, we conclude that: 1) breeding and age structure fluctuate in parallel in all bat species being considered; and 2) seasonal breeding shows a remarkably low interannual variability.

\section{Discussion}

Ultimate factors: assumptions. The analysis of the ultimate factors of seasonal breeding offered here is based on the explicit distinctions among "demand", "consumption", and "supply", and on postulates concerning the mutual relationships of these terms. Demand refers to the minimal fruit-crop within the joint home range of a population of frugivores required for all individuals to succeed in locating enough food to satisfy their vital needs.

Consumption refers to the portion of a fruit-crop actually depleted by a population of frugivores. That a demand was exerted can be inferred a priori, i.e. without the need of subsequent data, by merely detecting that a population of frugivores existed. Demand increases with population growth and as the proportional representation of critical, 
higher-demanding groups of individuals (females with advanced pregnancies, lactating females, juveniles, subadults) increases within the population. That a demand has been at least partially satisfied, and hence that consumption occurred, can be inferred a posteriori, i. e. with the aid of subsequent data, by detecting that a previously existing population of frugivores survived, and by observing that individuals belonging to the population successfully completed reproductive and age transitions (from nonpregnant to lactating female, from juvenile to adult). During a given period of the year, consumption should rarely equal and never exceed demand, because: 1) at times, fruit may become so scarce that starving occurs within the population of frugivores. When this happens, consumption is below the vital needs of the population and demand is not completely satisfied (demand exceeds consumption); and 2) demand has an "inflated" component owing to inefficiencies in the foraging of individual frugivores. For example, juveniles and subadults, owing to their inexperience, probably are the least efficient foragers within a population, and thus may demand that an abundant supply of fruit exists, of which they will consume only a small fraction, to be successful in locating meals often enough to survive. The third term needing clarification is "supply", here defined as the size of the fruit-crop available to a population of frugivores within its home range during a given period. Whenever demand exceeds supply, competition for fruit can be expected to occur among frugivores, and whenever supply exceeds consumption, competition for seed dispersal by frugivores can be expected to occur among plants. If plant-frugivore interactions were the only factor affecting demand, consumption, and supply, populations of frugivores should be selected to adjust both their demand and consumption to supply, and plant populations should be selected to adjust their supply to consumption.

\begin{tabular}{|c|c|c|c|}
\hline Data sets compared & Sample sizes $(n)$ & $r$ & $\begin{array}{c}\text { Bonferroni-corrected } \\
p \text {-value* }\end{array}$ \\
\hline Carollia 1982 vs. Carollia 1983 & 309 vs. 368 & 0.92 & $<3.7 \times 10^{-17}$ \\
\hline Carollia 1982 vs. Carollia multiyear ${ }^{1}$ & 309 vs. 253 & 0.91 & $<2.5 \times 10^{-16}$ \\
\hline Carollia 1983 vs. Carollia multiyear ${ }^{1}$ & 368 vs. 253 & 0.90 & $<8.6 \times 10^{-15}$ \\
\hline Carollia 1979-2007 vs. Sturnirini² & 930 vs. 285 & 0.94 & $<8.5 \times 10^{-27}$ \\
\hline Carollia $1979-2007$ vs. Stenodermatini ${ }^{3}$ & 930 vs. 554 & 0.92 & $<2.6 \times 10^{-22}$ \\
\hline Carollia $1979-2007$ vs. Stenodermatinae ${ }^{4}$ & 930 vs. 839 & 0.94 & $<4.3 \times 10^{-26}$ \\
\hline Sturnirini ${ }^{2}$ vs. Stenodermatini ${ }^{3}$ & 285 vs. 554 & 0.95 & $<1.2 \times 10^{-27}$ \\
\hline
\end{tabular}

Table 2. Pearson correlation coefficients and their $p$-values for seasonal changes in population composition between data sets involving Carollia brevicauda (full data, and three year/multiyear combinations), Sturnira species combined (full data), and stenodermatines including Sturnira (full data)."

*All correlations highly significant. 'Data obtained during 1979-1981 + 1984-2007. ${ }^{2}$ Sturnira bidens, S. bogotensis, S. erythromos, and S. ludovici combined (1979-2007). ${ }^{3}$ Artibeus lituratus, Dermanura bogotensis, Enchisthenes hartii, and Platyrrhinus umbratus combined (1979-2007). ${ }^{4}$ Sturnirini and Stenodermatini combined. For each data set, all breeding and age categories are considered collectively. See Methods for further explanation.

Ignorance of the specific metabolic requirements and foraging efficiencies of individuals belonging to each breeding category and age class precludes a quantitative estimate of the seasonal fluctuations in the amount of food demanded and consumed by the bat populations studied as a function of their phenologies. However, information available on insectivorous bats and other mammals (e. g. Migula 1969; Studier et al. 1973; Kunz 1974; Randolph 
et al. 1977; Racey and Speakman 1987; Heesen et al. 2013), that can be generalized to frugivorous bats, suggests that there are three critical groups:

A) Females with advanced pregnancies. Rapid growth of the fetus during late pregnancy can be expected to impose an important metabolic burden on these females. Moreover, considerable enlargement of the abdomen and increased body mass noticeably hinder their flight, suggesting that locomotion in these females is especially costly in energetic terms.

$B$ ) Lactating females. Unlike the former, these females are not obligated to carry their progeny with them permanently. However, because of the larger size and higher rate of absolute growth of newborn offspring, which increases energetic and nutritional requirements, and because translocation of energy and nutrients from mother to offspring through milk is less efficient than translocation through the placenta, lactating females should be the individuals supporting the highest metabolic burden.

C) Juveniles and subadults. They must attain adulthood leading an independent life. This should not imply a markedly different metabolic burden, especially energetic, with respect to adults. However, juveniles and subadults are inexperienced and can be expected to be less efficient foragers. To survive, they need a noncompetitive environment supplying easy to find, abundant food. Teaching and continued feeding by the mother, as reported for some bats (Kunz 1974; Schmidt and Manske 1973; Brigham and Brigham 1989), may ameliorate the necessity of easily obtained food.

Ultimate factors: inferences based on the preceding assumptions. With the previous definitions in mind, and recognizing females with advanced pregnancies, lactating females, and juveniles and subadults as critical groups, it becomes clear that marked fluctuations in both demand and consumption occur during the breeding season as a consequence of the female-breeding and age structure phenologies (Fig. 3, Table A1), and potential to double initial population size (assuming that females are 50\% of the population, and that each female produces one young twice a year), of the bat populations studied. Such fluctuations in demand and consumption during a successfully completed breeding season can be inferred to be the outcome of the following three main components:

A) Two peaks of demand, and two of consumption, resulting from the two peaks of abundance exhibited by the combination of females either showing advanced pregnancies or nursing their offspring.

$B$ ) Two peaks of inexperience-induced demand originating in the two peaks of abundance exhibited by the combination of juveniles and subadults (the second of these peaks partly extends beyond the breeding season, but its most intense portion occurs within its boundaries).

C) Two successive increases, in a stepwise fashion, in both demand and consumption caused by the two pulses of population growth.

Because the relative contribution of each of these three components cannot be quantified at present, the shape of the fluctuations in demand and consumption during the breeding season cannot be characterized with precision. However, it can be predicted that successfully completed breeding seasons, as those recorded in the present study, will generate demand and consumption curves showing some degree of bimodality owing to components " $A$ " and " $B$ ", and a net growth owing to component " $C$ ". It is clear that the demand curve cannot grow in this manner if the supply curve does not equal or exceed demand during the breeding season. Support for this notion 
of a coupling of demand to supply comes from the consumption curve, for its inferable bimodality and growth during successful breeding seasons implies that, in general, supply was at least sufficient to satisfy demand. Therefore, it can be concluded that the breeding seasons that occurred during the study (Fig. 3, Table A1) were also seasons of a relatively plentiful supply of food.

The results may also be interpreted as indicating that the season of short supply of food for the bat populations begins toward the last half of the second wet season. Evidence that may imply this includes:1) termination of breeding during the first half of the second wet season. This may be viewed as a demand-reducing strategy that would be adaptively meaningless unless supply has plummeted, or is to plummet soon and predictably, to well below the level of the demand exerted by bat populations; and 2) the diminished intensity of the second annual birth-pulse with respect to the first annual birth-pulse (Fig. 3). This diminishment may have a component due to recruitment into the adult age class of females born during the first annual birth-pulse of the same year, for which what remains of the breeding season is insufficient to breed. However, the diminishment is so marked that it cannot be fully explained by such recruitment. Therefore, it must also include another component due to females born in the preceding years skipping the second annual pregnancy more often than the first. This propensity of females to omit the second annual pregnancy is probably caused by the proximity of a seasonal short supply of food implying, as reported for other frugivorous mammals (e. g. Charles-Dominique et al. 1981), reduced survival probabilities for offspring born late in the breeding season. Four conclusions emerge from the preceding discussion:

First, marked seasonal fluctuations occur both in the demand exerted by the populations of frugivorous bats studied, and in the supply made available to such populations by food plants. These fluctuations cause supply to exceed consumption and demand during the breeding season, and demand to exceed supply during the nonbreeding season. When supply exceeds demand, competition for the seed-dispersal services provided by the bats should occur within and among the plant populations, with the bats wasting fruit and the plants wasting seeds. When demand exceeds supply, competition for fruit should occur within and among the bat populations, with the bats wasting individuals and the plants wasting seed dispersers. Therefore, the efficiency of the bat-plant mutualism suffers a reduction.

Second, the seasonal fluctuations in demand and supply implicate the presence of one or more distorting factors which, although extrinsic to bat-plant interactions, do affect the seasonal component of these interactions, for in the absence of such factors the evolutionary tendency of demand and consumption to adjust to supply, and of supply to adjust to consumption, would maximize the efficiency of the bat-plant mutualism by suppressing seasonal fluctuations of demand, supply, and consumption.

Third, hypothetically, extrinsic factors distorting bat-plant interactions could act upon the bats (in which case the seasonality of supply would have evolved in response to the seasonality of consumption), or upon the plants (in which case the seasonality of demand would have evolved in response to the seasonality of supply). Evidence supporting the first alternative is lacking. On the contrary, because a good number of both observational (e. g. Daubenmire 1972; Alexandre 1980; Opler et al. 1980; Foster 1982; Koptur et al. 1988) and manipulative (e. g. Opler et al. 1976; Augspurger 1982; Garwood 1982; Borchert 1983, 
1994) studies have concluded that the rainfall markedly affects the phenology of tropical forest plants, the most plausible option is to propose that the extrinsic factor distorting batplant interactions, and thus causing bimodal polyestry, is the average seasonal regime of rainfall, and that it affects such interactions by acting upon the plants.

Fourth, assuming that the seasonal peaks of supply track rainfall, seasonal breeding, with peaks of demand coinciding with peaks of supply, has a clear adaptive value for populations of frugivorous phyllostomids (coincidentally, it also benefits plant populations). Therefore, analogously to other authors (e. g. Fleming et al. 1972; Wilson 1979; Thomas and Marshall 1984; Dinerstein 1986), albeit more explicitly, we conclude that seasonal fluctuations in the availability of fruit, resulting from the seasonality of rainfall, appear to be the main selective force, or ultimate factor, that has led to the seasonal breeding pattern observed in frugivorous phyllostomid bats.

Another point needing discussion concerns the bimodality of bat breeding. Because the rainfall regime and annual temperature cycle of the study area are also bimodal (Fig. 1), it would be tempting to look for an ultimate or proximate cause-and-effect relationship (Mello et al. 2004, 2009). However, the observation that frugivorous phyllostomids inhabiting regions with unimodal rainfall also exhibit bimodal polyestry (e. g. LaVal and Fitch 1977; Bonaccorso 1979) suggests that there are other factors, common to unimodal and bimodal rainfall regimes, that alone are capable of inducing and maintaining bimodal polyestry. For example, giving birth a first time early and a second time late in the season of relatively plentiful supply, thus generating the two synchronous birth-pulses characteristic of bimodal polyestry, is perhaps the only way in which a majority of the females could accommodate two parturitions within the span of this season.

Proximate factors: questions. There are two ways in which a biological cycle synchronous with an environmental cycle could have arisen: a) endogenously, as a response to some physiological oscillator, internal to the organisms, whose period is synchronized with the period in the environment by means of an entraining time cue; or b) exogenously, as a direct response to some cyclic change in the environment (e. g. Brady 1979). Therefore, two broad questions may be posed concerning proximate factors. First, do the annual breeding cycles observed possess an endogenous component? Second, which is the environmental factor (either an entraining time cue, or a cyclic change with a direct effect) responsible for the onset and synchrony of each annual cycle? An exploration of these questions follows.

Arguments for an endogenous component. The low interannual variability and high degree of intra- and interspecific synchrony in the seasonal breeding cycles that we observed (Fig. 3, Table A1) suggest an endogenous control, unless synchrony owes to a shared exogenous factor lacking interannual variability (such as photoperiod). As emphasized by authors such as Immelmann (1971) and Gwinner (1975), the rigorous demonstration of an endogenous component in an annual cycle would require: a) removing a sample of the relevant organisms out of their natural environment; $b$ ) depriving these organisms of seasonal information by holding them under artificial constant conditions; and c) demonstrating the persistence of a circannual cycle, similar to the natural one, but with a periodicity shorter or longer than the natural one (if a circannual cycle has a period indistinguishable from 12 months, 
the possibility of an uncontrolled cyclic variable having affected the outcome cannot be conclusively excluded). To our knowledge, nobody has deliberately attempted to establish whether there is an endogenous component in the breeding seasonality of frugivorous phyllostomids by applying this procedure, though experiments in captivity have led to conclude that a nectarivorous phyllostomid, Anoura geoffroyi, does possess an endogenous component in its seasonally monoestrous breeding cycle (Heideman et al. 1992; Heideman and Bronson 1994). Nevertheless, four studies (Kleiman and Davis 1979; Kürten 1983; Porter 1979; Bonilla and Turriago 1986) contain information, relevant to frugivorous phyllostomids, concerning the periodicity of breeding in captive colonies of Carollia perspicillata maintained under artificial year-round uniform conditions (Table 3).

\begin{tabular}{|c|c|c|c|c|c|c|c|c|c|c|}
\hline 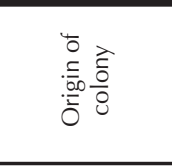 & 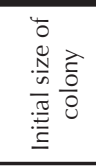 & 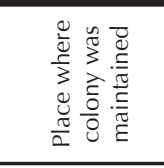 & $\begin{array}{l}\frac{.}{0} \\
\frac{0}{2} \\
\frac{0}{0} \\
\frac{0}{0} \\
\frac{\frac{C}{L}}{2}\end{array}$ & 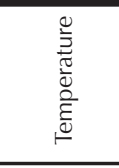 & 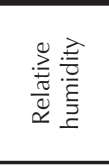 & $\stackrel{ \pm}{\circ}$ & 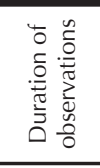 & 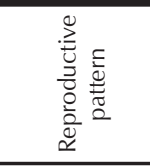 & $\begin{array}{l}0 \\
\stackrel{U}{\Xi} \\
0 \\
0\end{array}$ & $\begin{array}{lr}\text { Table } 3 . & \text { Breeding in } \\
\text { four captive } & \text { colonies } \\
\text { of Carollia } & \text { perspicillata } \\
\text { maintained } & \text { under } \\
\text { year-round } & \text { uniform }\end{array}$ \\
\hline $\begin{array}{l}\text { Canal Zone, } \\
\text { Panamá } \\
\left(9^{\circ} \mathrm{N}, 79^{\circ} \mathrm{W}\right)\end{array}$ & $\begin{array}{l}10 \text { 우우 } \\
6 \hat{\jmath} \hat{0}\end{array}$ & $\begin{array}{l}\text { Saint Louis, } \\
\text { MO, USA } \\
\left(39^{\circ} \mathrm{N}\right. \\
\left.90^{\circ} \mathrm{W}\right)\end{array}$ & $\begin{array}{l}12 \mathrm{~h} \\
\text { light } \\
12 \mathrm{~h} \\
\text { dark } \\
\text { inverted }\end{array}$ & $23-28^{\circ} \mathrm{C}$ & $60-90 \%$ & $\begin{array}{l}\text { Artificial, } \\
\text { constant }^{a}\end{array}$ & 3 years & $\begin{array}{l}\text { Bimodal } \\
\text { polyestry }\end{array}$ & 1 & conditions. \\
\hline $\begin{array}{l}\text { Trinidad, } \\
\text { West Indies } \\
\left(10^{\circ} \mathrm{N}, 61^{\circ} \mathrm{W}\right)\end{array}$ & $\begin{array}{l}11 \text { 우우 } \\
6 \hat{\jmath} \text { ภे }\end{array}$ & $\begin{array}{l}\text { Washington, } \\
\text { DC, USA } \\
\left(39^{\circ} \mathrm{N}\right. \\
\left.77^{\circ} \mathrm{W}\right)\end{array}$ & $\begin{array}{l}12 \mathrm{~h} \\
\text { light } \\
12 \mathrm{~h} \\
\text { dark } \\
\text { inverted }\end{array}$ & $27-31^{\circ} \mathrm{C}$ & $50-80 \%$ & $\begin{array}{l}\text { Artificial, } \\
\text { constant }^{a}\end{array}$ & 1 year & $\begin{array}{l}\text { Three } \\
\text { consecutive } \\
\text { birth-pulses }\end{array}$ & 2 & $\begin{array}{l}\text { aDiluted fruit-pulp } \\
\text { mixed with protein, } \\
\text { minerals, and vitamins; }\end{array}$ \\
\hline $\begin{array}{l}\text { Guanacaste, } \\
\text { Costa Rica } \\
\left(10^{\circ} \mathrm{N}, 85^{\circ} \mathrm{W}\right)\end{array}$ & $\begin{array}{l}11 \text { 우우 } \\
12 \hat{\jmath} \text { ते }\end{array}$ & $\begin{array}{l}\text { Bonn, } \\
\text { Germany } \\
\left(51^{\circ} \mathrm{N}, 7^{\circ} \mathrm{E}\right)\end{array}$ & $\begin{array}{l}12 \mathrm{~h} \\
\text { light } \\
12 \mathrm{~h} \\
\text { dark } \\
\text { inverted }\end{array}$ & $25^{\circ} \mathrm{C}$ & $80 \%$ & $\begin{array}{l}\text { Artificial, } \\
\text { constant }^{a}\end{array}$ & 1 year & $\begin{array}{l}\text { Bimodal } \\
\text { polyestry }\end{array}$ & 3,4 & $\begin{array}{l}\text { bthe birth-pulses were } \\
\text { well-synchronized } \\
\text { and at same time as } \\
\text { in the original wild } \\
\text { populations. }\end{array}$ \\
\hline $\begin{array}{l}\text { Villavicencio, } \\
\text { Colombia } \\
\left(4^{\circ} \mathrm{N}, 73^{\circ} \mathrm{W}\right)\end{array}$ & $\begin{array}{l}15 \text { 웅 } \\
3 \hat{\jmath} \delta^{2}\end{array}$ & $\begin{array}{l}\text { Bogotá, } \\
\text { Colombia } \\
\left(4^{\circ} \mathrm{N}, 74^{\circ} \mathrm{W}\right)\end{array}$ & $\begin{array}{l}9 \mathrm{~h} \text { light } \\
15 \mathrm{~h} \\
\text { dark } \\
\text { inverted }\end{array}$ & $18-22^{\circ} \mathrm{C}$ & $55-75 \%$ & $\begin{array}{l}\text { Artificial, } \\
\text { constant }^{a}\end{array}$ & 2 years & $\begin{array}{l}\text { Bimodal } \\
\text { polyestry }\end{array}$ & 5 & $\begin{array}{llr}\text { (1978, } 1979) ; & { }^{2} \text { Kleiman } \\
\text { and Davis } & (1979) ; \\
{ }^{3} \text { Kürten } & (1983) ; & { }^{4} \text { Laska } \\
(1990) ; & { }^{5} \text { Bonilla } & \text { and } \\
\text { Turriago (1986). } & \end{array}$ \\
\hline
\end{tabular}

The overall maintenance conditions of the four colonies were similar, and would appear unlikely to lead to divergent outcomes. The most tangible differences among the four studies involve the founder populations originating the colonies, which inhabit mutually distant areas, and the latitudes at which the colonies were maintained, which comprise a remarkably wide range. Results of two kinds were obtained: a) bimodal polyestry, with its characteristic nonbreeding phase intervening between pairs of birth-pulses, during six years of observations (Porter 1979; Kürten 1983; Bonilla and Turriago 1986); and b) three consecutive birth-pulses, with absence of a nonbreeding phase owing to most females giving birth thrice, during one year of observations (Kleiman and Davis 1979).

Because only Porter's (1979) information suggests a circannual breeding cycle with a period slightly differing from 12 months, and because even in this study such a trend was not sufficiently clear, it cannot be conclusively established whether an endogenous component was involved in the breeding of any of the colonies. Nevertheless, the most plausible explanation for the occurrence of bimodal polyestry in three of the colonies (Bonilla and Turriago 1986; Kürten 1983; Porter 1979) involves the contribution of some endogenous mechanism (as also suggested for a captive colony of Artibeus jamaicensis, see Keast Taft 
and Handley 1991), because an explanation directly involving exogenous time cues would require intervention of some environmental factor of a subtle and uncontrolled nature, such as an annual geophysical cycle or the seasonality of barometric pressure, unavoidably penetrating captive conditions and capable of initiating and synchronizing the circannual breeding cycles. This seems unlikely owing to four reasons. First, the geographical separation between the original wild populations and the Saint Louis and Bonn colonies is considerable (Table 3), requiring the hypothesized environmental factor to act similarly in such mutually distant regions as tropical America, temperate North America, and Europe. Second, if the environmental factor penetrated the captive conditions and led to bimodal polyestry in the Saint Louis and Bonn colonies (Kürten 1983; Porter 1979), it would be difficult to explain why it failed to do the same to the Washington colony (Kleiman and Davis 1979), which is intermediate in latitude (Table 3). Third, the synchrony initially observed in the Bonn colony (Kürten 1983) faded after four years (Laska 1990; for a similar result involving a captive colony of Artibeus jamaicensis, see Keast Taft and Handley 1991), so the environmental factor should also have faded. Fourth, if we assume, as we argue below, that food supply acts as the environmental regulator of the annual breeding cycles of frugivorous phyllostomids, the instances of bimodal poyestry observed in captive C. perspicillata occurred without cyclic fluctuations in such regulator. Therefore, based on this evidence, it would seem that there is at least some degree of endogenous predetermination in the annual breeding cycles of frugivorous phyllostomids.

On the other hand, assuming that the presence of a third annual birth-pulse in the Washington colony was not an artifact created by captive conditions, the Trinidadian population of $C$. perspicillata originating this colony could be aseasonally polyestrus, as proposed for frugivorous phyllostomids in some localities (Estrada and Coates-Estrada 2001; Montiel et al. 2011), or the annual breeding cycle of this population might owe to a differently timed endogenous component.

Arguments against an endogenous component. Frugivorous and insectivorous phyllostomids, and frugivorous pteropids, are known to have a postpartum oestrus (e. g. Ramakrishna 1947; Fleming 1971; Laska 1990; Kofron 1997, 2007a, b; Dechmann et al. 2005), and delayed development of the fetus (e. g. Bradshaw 1962; Fleming 1971; Burns and Easley 1977; Heideman 1989b; Kofron 1997, 2007a, b; Badwaik and Rasweiler 2001; Meenakumari and Krishna 2005). Accordingly, a possible and most general explanation for the regulation of the annual breeding cycles of frugivorous phyllostomids (and pteropids) would involve a complete absence of an endogenous component (and therefore no need of an entraining time cue), with reproductively mature females being pregnant all year round. As a direct physiological response to limiting energetic and nutritional budgets, during the food shortage season females would carry barely developed fetuses (thus not showing externally evident pregnancies) implying a minimal metabolic burden. As a direct physiological response of a highly favorable energetic and nutritional budget, during the food abundance season females would carry quickly growing fetuses (thus showing externally evident pregnancies) implying a high metabolic burden. This process would result in a majority of mature females showing externally evident pregnancies during certain parts of the year, generating the patterns that have been described as bimodal polyestry, seasonal polyestry, or aseasonal polyestry when the fruiting season is long (e. g. Wilson 1979; Estrada and Coates-Estrada 2001; Montiel et al. 
2011; this study), or seasonal monoestry when the fruiting season is short (e .g. Stoner 2001; Duarte and Talamoni 2010). In this context, the remarkably high interspecific synchrony and low interannual variability in the annual breeding cycles of nine sympatric species of frugivorous phyllostomids in cloud forests of the Venezuelan Andes (Fig. 2; Table A1) would be a simple and direct consequence of similar fruiting phenologies, both within and among years, of all bat species specific, or bat guild specific, food plant assemblages involved. Likewise, absence of interspecific synchrony in the annual breeding cycles of sympatric species of frugivorous phyllostomids reported in other studies (e. g. Estrada and CoatesEstrada 2001; Montiel et al. 2011) would reflect intra-annual differences in the fruiting phenologies of the food plant assemblages involved.

Nature of time cues. Here, we discuss the possible nature of the exogenous time cues of the annual breeding cycles of frugivorous phyllostomids mainly under the hypothesis that such cycles possess some degree of endogenous predetermination.

At a given latitude, potential entraining time cues belong to two fundamental types: those with a fixed seasonal schedule and lacking local variability, typified by photoperiod; and those showing interannual and local variability, such as rainfall, temperature, and fruiting phenology. There are two natural situations that would lead to discard potential entraining time cues of the first type. These are:

A) One or more pairs of populations of the same species living so close geographically that latitude and genetic factors do not differ significantly between them, yet start their breeding seasons at different times of the year. This situation was exemplified by Fleming et al. (1972), who reported frugivorous phyllostomids (Carollia perspicillata, Artibeus jamaicensis) from two localities in the Panama Canal Zone to initiate their breeding season about one month later than conspecifics from a Costa Rican locality. Fleming et al. (1972) argued that the breeding seasons correlated better with the rainfall regimes, locally variable, than with photoperiod, almost identical in the three localities, and therefore proposed rainfall as the proximate factor, or entraining time cue, for these cycles.

$B$ ) Breeding seasons showing interannual variation in their seasonal schedule in a single locality, either relatively, i. e., sequential order in which several species initiate breeding, or absolutely, i. e., exact time of the year in which a given species initiates breeding. Our study is relevant to this situation, but does not exemplify it because we did not detect differences among years (Table 2). Therefore, our results would be consistent with photoperiod, or any other variable with a fixed seasonal schedule at our latitude, being potential entraining time cues, a possibility that is negated by the findings of Fleming et al. (1972). We should note that, owing to its highly reduced oscillations at low latitudes, photoperiod is thought to be unimportant as an entraining time cue in the annual cycles of tropical animals (Immelmann 1971). Moreover, it has been concluded that seasonal breeding in Anoura geoffroyi, a nectarivorous phyllostomid, is not affected by photoperiod (Heideman et al. 1992; Heideman and Bronson 1994). On the other hand, our finding of a low interannual variability in the seasonal schedule of breeding (Table 2) in spite of a marked interannual variation in the rainfall pattern (Figs. 1 and 2 ) is not consistent with rainfall being a potential entraining time cue, as proposed by Fleming et al. (1972).

Based on the above reasoning, we disregard photoperiod, or any other variable with a similar fixed seasonal schedule, and rainfall, or anything dependent on it in a direct and 
simple manner, as potential entraining time cues. Thus, potential entraining time cues left to consider are seasonal fluctuations in temperature, as proposed by Mello et al. (2004, 2009) for neotropical bats, and availability of fruit, as proposed by Heideman (1988) for paleotropical frugivorous bats. We also disregard the possibility of temperature being a potential entraining time cue on the following grounds: 1) interannual variability in the monthly pattern of temperature fluctuations is just as large, proportionally, as in the case of rainfall (Fig. 1), and this did not translate into differences that we could detect among breeding seasons of different years (Table 2); 2) in general, temperature is thought to be unimportant as an entraining time cue in the annual cycles of homeotherms, including those inhabiting temperate zones (Gwinner 1975; Brady 1979), in which maximum and minimum average monthly temperature differs much more than in the tropics (in our study area this difference reaches only $2^{\circ} \mathrm{C}$; Figure 1$) ; 3$ ) in major mountain ranges, such as the Venezuelan Andes, foraging along a sharp altitudinal gradient or shifting refuges at various elevations by the bats would disrupt the physiologically perceived seasonal change of temperature, with unpredictable effects on reproductive synchronization; and 4) because cave temperatures often are comparatively stable, cave-dwelling frugivorous bats might have a reduced opportunity to depend on monthly oscillations in temperature as an entraining time cue for their annual breeding cycles.

On the other hand, seasonal fluctuations in the availability of fruit, the only variable left in our list, would seem to have good potential to act as the entraining time cue that we are trying to identify owing to four reasons. First, throughout the tropics, frugivorous bats generally concentrate breeding in the months during which, in the average year, rainfall tends to be more intense (e. g. Bonaccorso 1979; Thomas and Marshall 1984; Dinerstein 1986; Heideman 1988; Kofron 1997; Bumrungsri et al. 2007; Duarte and Talamoni 2010; Durant et al. 2013), this being an indication of the entraining time cue being related to rainfall, though, as we have said, not in a direct or simple manner. Second, plant phenology, including fruiting phenology, is well-known to respond to the seasonality of rainfall with an attenuated monthly and interannual variation owing to rainwater stored in the subsoil and in plant structural components buffering such seasonality (Borchert 1994; Bohlman et al. 1995; Meinzer et al. 1999). Third, there can be no doubt that fruiting phenology is capable of affecting directly and strongly the populations of frugivorous bats. Fourth, seasonal fluctuation in the availability of fruit has been proposed to act as the entraining time cue for other tropical frugivorous vertebrates (Ward 1969; Fogden 1972; Jones and Ward 1976; Snow 1976; Worthington 1982; Heideman 1988). Therefore, we conclude that the seasonality of fruit production is likely to be the environmental factor modulating the annual breeding cycles of frugivorous phyllostomid bats, irrespective of whether it does so indirectly as a time cue entraining endogenous rhythms (under the assumption that breeding cycles do possess an endogenous component), or directly as a limiting environmental factor seasonally allowing or impeding bat breeding and population growth (under the assumption that breeding cycles do not possess an endogenous component).

\section{Acknowledgments}

Thanks are due to D. E. Wilson for reading an early version of the manuscript and formulating valuable comments. 
Alexandre, D. Y. 1980. Caractère saisonnier de la fructification dans une forêt hygrophile de Côte d'Ivoire. Revue d'Ecologie (La Terre et la Vie) 34:335-359.

Ataroff, M., and L. Sarmiento. 2003. Diversidad en los Andes de Venezuela. I. Mapa de unidades ecológicas del estado Mérida. Ediciones del Instituto de Ciencias Ambientales y Ecológicas (ICAE). Universidad de Los Andes. Mérida, Venezuela.

Augspurger, C. K. 1982. A cue for synchronous flowering. Pp. 133-150 en the ecology of a tropical forest - seasonal rhythms and long-term changes (Leigh, E. G. Jr., A. S. Rand, and D. M. Windsor, eds.). Smithsonian Institution Press. Washington, USA.

BadwaIK, N. K., aND J. J. Rasweiler IV. 2001. Altered trophoblastic differentiation and increased trophoblastic invasiveness during delayed development in the short-tailed fruit bat, Carollia perspicillata. Placenta 22:124-144.

BaranGa, J. 1980. The adrenal weight changes of a tropical fruit bat, Rousettus aegyptiacus E. Geoffroy. Zeitschrift für Säugetierkunde 45:321-336.

Bates, B. T., S. Zhang, J. S. Dufek, and F. C. Chen. 1996. The effects of sample size and variability on the correlation coefficient. Medicine and Science in Sports and Exercise 28:386-391.

Bentos, T. V., R. C. Mesquita, and G. B. Wiluamson. 2008. Reproductive phenology of central Amazon pioneer trees. Tropical Conservation Science 1:186-203.

Bernard, E. 2002. Diet, activity and reproduction of bat species (Mammalia, Chiroptera) in Central Amazonia, Brazil. Revista Brasileira de Zoologia 19:173-188.

Bernard, R. T. F., and G. S. Cumming. 1997. African bats: evolution of reproductive patterns and delays. Quarterly Review of Biology 72:253-274.

Bonaccorso, F. J. 1979. Foraging and reproductive ecology in a Panamanian bat community. Bulletin of the Florida Museum of Natural History, Biological Sciences 24:359-408.

Bonaccorso, F. J., N. Smythe, AND S. R. Humphrey. 1976. Improved techniques for marking bats. Journal of Mammalogy 57:181-182.

Bohlman, S. A., T. J. Matelson, and N. M. Nadkarni. 1995. Moisture and temperature patterns of canopy humus and forest floor soil of a montane cloud forest, Costa Rica. Biotropica 27:13-19.

Bonilla, H. De, AND G. TurRiago. 1986. Reproducción y comportamiento de una colonia de murciélagos Carollia perspicillata en cautividad. Acta Biológica Colombiana 1:99110.

Bonilla, H. DE, AND G.TurRiago. 1988. Ciclo reproductivo del murciélago Carollia perspicillata en el campo. Acta Biológica Colombiana 1:49-61.

BorChert, R. 1983. Phenology and control of flowering in tropical trees. Biotropica 15:8189.

BORCHERT, R. 1994. Soil and stem water storage determine phenology and distribution of tropical dry forest trees. Ecology 75:1437-1449.

Brady, J. 1979. Biological Clocks. Edward Arnold. London, UK.

Bradshaw, G. V. 1962. Reproductive cycle of the California leaf-nosed bat, Macrotus californicus. Science 136:645-646.

Brigham, R. M., and A. C. Brigham. 1989. Evidence for association between a mother bat and its young during and after foraging. American Midland Naturalist 121:205-207. 
Bumrungsri, S., W. Bumrungsri, and P. A. Racey. 2007. Reproduction in the short-nosed fruit bat in relation to environmental factors. Journal of Zoology 272:73-81.

Burns, J. M., and R. G. Eastey, R. G. 1977. Hormonal control of delayed development in the California leaf-nosed bat, Macrotus californicus: III. Changes in plasma progesterone during pregnancy. General and Comparative Endocrinology 32:163-166.

Carnegie, S. D., L. M. Fedigan, and A. D. Meln. 2011. Reproductive seasonality in female capuchins (Cebus capucinus) in Santa Rosa (Área de Conservación Guanacaste), Costa Rica. International Journal of Primatology 32:1076-1090.

Cerqueira, R., M. V. Vieira, and L. O. Salles. 1989. Habitat and reproduction of Rhipidomys cearanus at São Benedito, Ceará (Rodentia, Cricetidae). Ciência e Cultura, São Paulo 41:1009-1003.

Chaverri, G., AND T. H. Kunz. 2006. Reproductive biology and postnatal development in the tent-making bat Artibeus watsoni (Chiroptera: Phyllostomidae). Journal of Zoology 270:650-656.

Charles-Dominique, P. 1977. Ecology and behavior of nocturnal primates. Duckworth. London, UK.

Charles-Dominique, P., M. Atramentowicz, M. Charles-Dominique, H. Gérard, Hladik, A., Hladik, C. M., and M. F. Prévost. 1981. Les mammifères arboricoles nocturnes d'une forêt guyanaise: inter-relations plantes-animaux. Revue d'Ecologie (La Terre et la Vie) 35:341-435.

Cosson, J. F., and M. Pascal. 1994. Stratégie de reproduction de Carollia perspicillata (L., 1758) (Chiroptera, Phyllostomidae) en Guyane Française. Revue d'Ecologie (La Terre et la Vie) 49:117-137.

Croat, T. B. 1975. Phenological behavior of habit and habitat classes on Barro Colorado Island (Panama Canal Zone). Biotropica 7:270-277.

Curtin, F., And P. Schulz. 1998. Multiple correlations and Bonferroni's correction. Biological Psychiatry 44:775-777.

Daubenmire, R. 1972. Phenology and other characteristics of tropical semi-deciduous forest in northwestern Costa Rica. Journal of Ecology 60:147-170.

Dechmann, D. K., E. K. KalKo, B. KöniG, and G. Kerth. 2005. Mating system of a Neotropical roost-making bat: the white-throated, round-eared bat, Lophostoma silvicolum (Chiroptera: Phyllostomidae). Behavioral Ecology and Sociobiology 58:316-325.

DineRSTEIN, E. 1986. Reproductive ecology of fruit bats and the seasonality of fruit production in a Costa Rican cloud forest. Biotropica 18:307-318.

Duarte, A. P. G., and S. A. Talamoni. 2010. Reproduction of the large fruit-eating bat Artibeus lituratus (Chiroptera: Phyllostomidae) in a Brazilian Atlantic forest area. Zeitschrift für Säugetierkunde 75:320-325.

Durant, K. A., R. W. Hall, L. M. Cisneros, R. M. Hyland, and M. R. Willig. 2013. Reproductive phenologies of phyllostomid bats in Costa Rica. Journal of Mammalogy 94:14381448.

Emmons, L. H. 1980. Ecology and resource partitioning among nine species of African rain forest squirrels. Ecological Monographs 50:31-54.

Estrada, A., And R. Coates-Estrada. 2001. Species composition and reproductive phenology of bats in a tropical landscape at Los Tuxtlas, Mexico. Journal of Tropical Ecology 17:627-646. 
Fayenuwo, J. O., AND L. B. Halstead. 1974. Breeding cycle of the straw-colored fruit bat, Eidolon helvum, at Ile-Ife, Nigeria. Journal of Mammalogy 55:453-454.

Feer, F. 1989. Comparaison des régimes alimentaires de Cephalophus callipygus et $C$. dorsalis, Bovidés sympatriques de la forêt sempervirente africaine. Mammalia 53:563-604.

Fleming, T. H. 1971. Artibeus jamaicensis: delayed embryonic development in a Neotropical bat. Science 171:402-404.

Fleming, T. H. 1973. The reproductive cycles of three species of opossums and other mammals in the Panama Canal Zone. Journal of Mammalogy 54:439-455.

Fleming, T. H., and E. R. Heithaus. 1986. Seasonal foraging behavior of the frugivorous bat Carollia perspicillata. Journal of Mammalogy 67:660-671.

Fleming, T. H., E.T . Hooper, AND D. E. Wilson. 1972. Three Central American bat communities: structure, reproductive cycles, and movement patterns. Ecology 53:555-569.

FoGDEN, M. P. L. 1972. The seasonality and population dynamics of equatorial forest birds in Sarawak. Ibis 114:307-343.

Foster, M. S. 1975. The overlap of molting and breeding seasons in some tropical birds. Condor 77:304-314.

Foster, M. S. 1977. Ecological and nutritional effects of food scarcity on a tropical frugivorous bird and its fruit source. Ecology 58:73-85.

Foster, R. B. 1982. The seasonal rhythm of fruitfall on Barro Colorado Island. Pp. 151172 en The ecology of a tropical forest - seasonal rhythms and long-term changes (Leigh, E. G. Jr., Rand, A. S., and D. M. Windsor, eds.). Smithsonian Institution Press. Washington, USA.

Frankie, G. W., H. G. Baker, and P. A. Opler. 1974. Comparative phenological studies of trees in tropical wet and dry forests in the lowlands of Costa Rica. Journal of Ecology 68:167-188.

GanNon, M. R. 1994. A new method for marking bats. Bat Research News 34:88-89.

Garwood, N. C. 1982. Seasonal rhythm of seed germination in a semideciduous tropical forest. Pp. 173-185 en the ecology of a tropical forest - seasonal rhythms and longterm changes (Leigh, E. G. Jr., A. S. Rand, and D. M. Windsor, eds.). Smithsonian Institution Press. Washington, USA.

Gautier-Hıon, A., J.-M. Duplantier, L. Emmons, F. Feer, P. Heckestweiler, A. Moungazi, R. Quris, AND C. Sourd. 1985. Coadaptation entre rythmes de fructification et frugivorie en forêt tropicale humide du Gabon: mythe ou réalité. Revue d’Ecologie (La Terre et la Vie) 40:405-434.

Glanz, W. E., R. W. Thorington, JR., J. Giacalone-Madden, and L. R. Heany. 1982. Seasonal food use and demographic trends in Sciurus granatensis. Pp. 239-252 in The ecology of a tropical forest - seasonal rhythms and long-term changes (Leigh, E. G. Jr., A. S. Rand, and D. M. Windsor, eds.). Smithsonian Institution Press. Washington, USA.

Guıwicz, J. 1984. Population dynamics of the spiny rat Proechimys semispinosus on Orchid Island (Panama). Biotropica 16:73-78.

Goldizen, A. W., J. Terborgh, F. Cornejo, D. T. Porras, and R. Evans. 1988. Seasonal food shortage, weight loss, and the timing of births in saddle-back tamarins (Saguinus fuscicollis). Journal of Animal Ecology 57:893-901. 
Graham, G. L. 1987. Seasonality of reproduction in Peruvian bats. Fieldiana Zoology (New Series) 39:173-186.

Gwinner, E. 1975. Circadian and circannual rhythms in birds. Pp. 221-228 en: Avian biology (Farner, D. S., and J. R. King Eds.). Academic Press. New York, EE.UU.

Haldar, C., AND R. Yadav. 2006. Annual reproductive synchronization in ovary and pineal gland function of female short-nosed fruit bat, Cynopterus sphinx. Comparative Biochemistry and Physiology A 144:395-400.

Harrison, J. L. 1955. Data on the reproduction of some Malayan mammals. Proceedings of the Zoological Society of London 125:445-460.

Haugaasen, T., and C. A. Peres. 2005. Tree phenology in adjacent Amazonian flooded and unflooded Forests. Biotropica 37:620-630.

Heany, L. R., and R. W. Thorington, JR. 1978. Ecology of Neotropical red-tailed squirrels Sciurus granatensis, in the Panama Canal Zone. Journal of Mammalogy 59:846-851.

Heesen, M., S. Rogahn, J. Ostner, and O. Schülke. 2013. Food abundance affects energy intake and reproduction in frugivorous female Assamese macaques. Behavioral Ecology and Sociobiology 67:1053-1066.

Heideman, P. D. 1988. The timing of reproduction in the fruit bat Haplonycteris fischeri (Pteropodidae): geographic variation and delayed development. Journal of Zoology 215:577-595.

Heideman, P. D. 1989a. Delayed development in Fischer's pygmy fruit bat, Haplonycteris fischeri, in the Philippines. Journal of reproduction and Fertility 85:363-382.

Heideman, P. D. 1989b. Temporal and spatial variation in the phenology of flowering and fruiting in a tropical rainforest. Journal of Ecology 77:1059-1079.

Heideman, P. D., AND F. H. Bronson. 1994. An endogenous circannual rhythm of reproduction in a tropical bat, Anoura geoffroyi, is not entrained by photoperiod. Biology of Reproduction 50:607-614.

Heideman, P. D., Deoras, P., and F. H. Bronson. 1992. Seasonal reproduction of a tropical bat, Anoura geoffroyi, in relation to photoperiod. Journal of Reproduction and Fertility 96:765-773.

Heideman, P. D., and K. S. Powell. 1998. Age specific reproductive strategies and delayed embryonic development in an old world fruit bat, Ptenochirus jagori. Journal of Mammalogy 79:295-311.

Heithaus, E. R., T. H. Fleming, and P. A. Opler. 1975. Foraging patterns and resource utilization in seven species of bats in a seasonal tropical forest. Ecology 56:841-854.

Hutry, S. L. 1980. Flowering and fruiting periodicity in a premontane rain forest of Pacific Colombia. Biotropica 12:292-306.

HutCheON, J. M., J. A. KIRSCH, AND T. Garland JR. 2002. A comparative analysis of brain size in relation to foraging ecology and phylogeny in the Chiroptera. Brain, Behavior and Evolution 60:165-180.

ImmelmanN, K. 1971. Ecological aspects of periodic reproduction. Pp. 341-389 in Avian biology, Vol. 1 (Farner, D. S., and J. R. King, eds.). Academic Press. New York, EE.UU.

JACKSON, J. F. 1981. Seed size as a correlate of temporal and spatial patterns of seed fall in a Neotropical forest. Biotropica 13:121-130.

Janson, C. H., Terborgh, J., and L. H. Emmons. 1981. Non-flying mammals as pollinating agents in the Amazonian forest. Biotropica 13(Supplement):1-6. 
JONES, P. J., AND P. WARD. 1976. The level of reserve protein as the proximate factor controlling the timing of breeding and clutch-size in the red-billed quelea Quelea quelea. Ibis 118:547-574.

Keast Taft, L., and C. O. Handley, JR. 1991. Reproduction in a captive colony. Pp. 19-41 en demography and natural history of the common fruit bat, Artibeus jamaicensis, on Barro Colorado Island, Panama (Handley, C. O., Jr., Wilson, D. E., and A. L. Gardner, eds.). Smithsonian Contributions to Zoology 511, Smithsonian Institution Press. Washington, EE.UU.

Kleiman, D. G., AND T. M. Davis. 1979. Ontogeny and maternal care. Special publications, The Museum, Texas Tech University 16:387-402.

Kofron, C. P. 1997. Reproduction of two species of congeneric fruit bats (Cynopterus) in Brunei, Borneo. Journal of Zoology 243:485-506.

Kofron, C. P. 2007a. Reproduction of the dusky fruit bat Penthetor lucasi (Pteropodidae) in Brunei, Borneo. Mammalia 71:166-171.

Kofron, C. P. 2007b. Reproduction of the spotted-winged fruit bat Balionycteris maculata (Thomas 1893) in Brunei, Borneo (Megachiroptera Pteropodidae). Tropical Zoology 20:187-195.

Koptur, S., W. A. Haber, G. W. Frankie, and H. G. Baker. 1988. Phenological studies of shrub and treelet species in tropical cloud forests of Costa Rica. Journal of Tropical Ecology 4:323-346.

Kunz, T. H. 1974. Feeding ecology of a temperate insectivorous bat (Myotis velifer). Ecology 55:693-711.

Kunz, T. H., AND E. L. P. Anthony. 1982. Age estimation and post-natal growth in the bat Myotis lucifugus. Journal of Mammalogy 63:23-32.

KüRTEN, L. 1983. Haltung un Zucht der neotropischen Fledermaus Carollia perspicillata. Zeitschrift des Kölner Zoo 26:53-57.

LASKA, M. 1990. Gestation period and between-birth intervals in Carollia perspicillata (Phyllostomidae, Chiroptera). Journal of Zoology 222:697-702.

LaVAL, R. K., AND H. S. Fitch. 1977. Structure, movements, and reproduction in three Costa Rican bat communities. Occasional Papers of the Museum of Natural History, University of Kansas 69:1-28.

LeCk, C. F. 1972. Seasonal changes in feeding pressures of fruit- and nectar-feeding birds in Panama. Condor 74:54-60.

Leighton, M., AND D. R. Leighton. 1983. Vertebrate responses to fruiting seasonality within a Bornean rain forest. Pp. 181-196 en Tropical Rain Forest: Ecology and Management (Sutton, S. L., Whitmore, T. C., and A. C. Chadwick, eds.). Blackwell. Oxford, Rino Unido.

Lieberman, D. 1982. Seasonality and phenology in a dry tropical forest in Ghana. Journal of Ecology 70:791-806.

Marshall, A. G., and A.N. McWilliam. 1982. Ecological observations on epomorphine fruit-bats (Megachiroptera) in West African savanna woodland. Journal of Zoology 198:53-67.

McNAB, B. K. 1976. Seasonal fat reserves of bats in two tropical environments. Ecology 57:332-338. 
Medway, L. 1972. Phenology of a tropical rain forest in Malaya. Biological Journal of the Linnean Society 4:117-146.

Meenakumari, K. J., and A. Krishna. 2005. Delayed embryonic development in the Indian short-nosed fruit bat, Cynopterus sphinx. Zoology 108:131-140.

Meinzer, F. C., J. L. Andrade, G. Goldstein, N. M. Holbrook, J. Cavelier, and S. J. Wright. 1999. Partitioning of soil water among canopy trees in a seasonally dry tropical forest. Oecologia 121:293-301.

Mello, M. A. R., ANd F. A. S. Fernandez. 2000. Reproductive ecology of the bat Carollia perspicillata (Chiroptera: Phyllostomidae) in a fragment of the Brazilian Atlantic coastal forest. Mammalian Biology. Zeitschrift für Säugetierkunde 65:340-349.

Mello, M. A. R., E. K. V. KalKo, AND W. R.Silva. 2009. Ambient temperature is more important than food availability in explaining reproductive timing of the bat Sturnira lilium (Mammalia: Chiroptera) in a montane Atlantic Forest. Canadian Journal of Zoology 87:239-245.

Mello, M. A. R., G. M. Schittini, P. Selig, and H. G. Bergallo. 2004. A test of the effects of climate and fruiting of Piper species (Piperaceae) on reproductive patterns of the bat Carollia perspicillata (Phyllostomidae). Acta Chiropterologica 6:309-318.

Mena, J. L, and M. Williams de Castro. 2002. Diversidad y patrones reproductivos de quirópteros en una área urbana de Lima, Perú. Ecología Aplicada 1:1-8.

Mıgula, P. 1969. Bioenergetics of pregnancy and lactation in European common vole. Acta Theriologica 14:167-179.

Molinarı, J. 1993. El mutualismo entre frugívoros y plantas en las selvas tropicales: aspectos paleobiologicos, autoecologías, papel comunitario. Acta Biologica Venezuelica 14:1-44.

Monadjem, A., And A. E. Reside. 2012. Breeding season of Epomophorus walhbergi in the Lowveld of Swaziland. African Zoology 47:321-325.

Montiel, S., A. Estrada, ANd P. LEón. 2011. Reproductive seasonality of fruit-eating bats in northwestern Yucatan, Mexico. Acta Chiropterologica 13:139-145.

Moreau, R. E. 1937. Breeding seasons of birds in East African evergreen forest. Proceedings of the Zoological Society of London 1936:631-653.

Morton, E. S. 1977. Intratropical migration in the yellow-green vireo and piratic flycatcher. Auk 94:97-106.

Mutere, F. A. 1967. The breeding biology of equatorial vertebrates: reproduction in the fruit bat Eidolon helvum, at latitude $0^{\circ} 20^{\prime}$ S. Journal of Zoology 153:153-161.

Mutere, F. A. 1968. The breeding biology of the fruit bat Rousettus aegyptiacus E. Geoffroyi living at $0^{\circ} 22^{\prime}$ S. Acta Tropica 25:97-108.

Netson, J. E. 1965. Movements of Australian flying foxes (Pteropodidae: Megachiroptera). Australian Journal of Zoology 13:53-73.

O'Connell, M. A. 1979. Ecology of didelphid marsupials from northern Venezuela. Pp. 7387 en Vertebrate Ecology in the Northern Neotropics (Eisenberg, J. F., ed.). Smithsonian Institution Press. Washington, EE.UU.

ОкіА, N. O. 1974a. The breeding pattern of the eastern epauletted bat, Epomophorus anurus Heuglin, in Uganda. Journal of Reproduction and Fertility 37:27-31.

ОкіА, N. О. 1974b. Breeding in Franquet's bat, Epomophorus franqueti (Tomes), in Uganda. Journal of Mammalogy 55:462-465. 
ОкіА, N. O. 1987. Reproductive cycles of East African bats. Journal of Mammalogy 68:138141.

Opler, P. A., G. W. Frankie, and H. G. Baker. 1976. Rainfall as a factor in the release, timing, and synchronization of anthesis by tropical trees and shrubs. Journal of Biogeography 3:231-236.

Opler, P. A., G. W. Frankie, and H. G. Baker. 1980. Comparative phenological studies of treelet and shrub species in tropical wet and dry forests in the lowlands of Costa Rica. Journal of Ecology 68:167-188.

Penzhorn, B. L., and I. L. RautenbaCh. 1988. Reproduction of the Egyptian fruit bat Rousettus aegyptiacus in the southern tropics. South African Journal of Wildlife Research 18:8892.

Peres, C. A. 1994. Primate responses to phenological changes in an Amazonian terra firme forest. Biotropica 26:98-112.

Porter, F. L. 1978. Roosting patterns and social behavior in captive Carollia perspicillata. Journal of Mammalogy 59:627-630.

Porter, F. L. 1979. Social behavior in the leaf-nosed bat, Carollia perspicillata. I. Social organization. Zeitschrift für Tierpsychologie 49:406-417.

RaceY, P. A. 1982. Ecology of bat reproduction. Pp. 57-104 en Ecology of Bats (Kunz, T. H., ed.). Plenum. New York, EE.UU.

Racey, P. A., and J. R. Speakman. 1987. The energy costs of pregnancy and lactation in heterothermic bats. Symposia of the Zoological Society of London 57:107-125.

Ramakrishna, P. A. 1947. Post-partum oestrus in the short-nosed fruit bat, Cynopterus sphinx. Current Science 16:186.

Randolph, P. A., J. C. Randolph, K. Mattingly, and M. M. Foster. 1977. Energy costs of reproduction in the cotton rat, Sigmodon hispidus. Ecology 58:31-45.

Richter, H. V., AND Cumming, G. S. 2006. Food availability and annual migration of the strawcolored fruit bat (Eidolon helvum). Journal of Zoology 268:35-44.

Roosmalen, M. G. M. van, and L. L. Kuein. 1988. The spider monkeys, genus Ateles. Pp. 455-537 in Ecology and Behavior of Neotropical Primates (Mittermeier, R. A., A. Coimbra-Filho, and A.B. Fonseca, eds.). World Wildlife Fund. Washington, EE.UU.

Schaik, C. P. van. 1986. Phenological changes in a Sumatran rain forest. Journal of Tropical Ecology 2:327-347.

Schmidt, U., AND U. MANSkE. 1973. Die Jugendentwicklung der Vampirfledermäuse (Desmodus rotundus). Zeitschrift für Säugetierkunde 38:14-33.

SкUтсн, A. F. 1950. The nesting seasons of Central American birds in relation to climate and food supply. Ibis 92:185-222.

Smythe, N. 1978. The natural history of the Central American agouti (Dasyprocta punctata). Smithsonian Contributions to Zoology 257:1-52.

Smrthe, N. 1986. Competition and resource partitioning in the guild of Neotropical terrestrial frugivorous mammals. Annual Review of Ecology and Systematics 17:169-188.

Smythe, N., W. E. Glanz, and E. G. Leigh, Jr. 1982. Population regulation in some terrestrial frugivores. Pp. 227-238 en The ecology of a tropical forest - seasonal rhythms and long-term changes (Leigh, E. G. Jr., Rand, A. S., and D. M. Windsor, eds.). Smithsonian Institution Press. Washington, EE.UU. 
SNow, D. W. 1976. The relationship between climate and annual cycles in the Cotingidae. Ibis 118:366-401.

Snowdon, C. T., And P.Solnı. 1988. The tamarins, genus Saguinus. Pp. 223-298 in Ecology and behavior of neotropical primates (Mittermeier, R. A., A. Coimbra-Filho, and A. B. Fonseca, eds.). World Wildlife Fund. Washington, EE.UU.

Sosa, M., and P. R. Ramoni-Perazzi. 1995. Reproductive pattern of Artibeus jamaicensis Leach, 1821 and A. lituratus (Olfers, 1818) (Chriroptera: Phyllostomidae), in an arid zone of Venezuelan Andes. Revista Brasileira de Biologia 55:705-713.

StONER, K. E. 2001. Differential habitat use and reproductive patterns of frugivorous bats in tropical dry forest of northwestern Costa Rica. Canadian Journal of Zoology 79:16261633.

Studier, E. H., V. L. Lysengen, and M. J. O'Farrell. 1973. Biology of Myotis thysanodes (Chiroptera: Vespertilionidae) - II. Bioenergetics of pregnancy and lactation. Comparative biochemistry and physiology A 44:467-471.

TADDEl, V. A. 1976. The reproduction of some Phyllostomidae (Chiroptera) from the northwestern region of the State of São Paulo. Boletim de Zoologia, Universidade de São Paulo 1:313-330.

Terborgh, J. 1983. Five New World primates - a study in comparative ecology. Princeton University Press. Princeton, EE.UU.

Thomas, D. W. 1983. The annual migrations of three species of West African fruit bats (Chiroptera: Pteropodidae). Canadian Journal of Zoology 61:2266-2272.

Thomas, D. W., AND A. G. Marshall. 1984. Reproduction and growth in three species of West African fruit bats. Journal of Zoology 202:265-281.

WARD, P. 1969. The annual cycle of the yellow-vented bulbul Pycnonotus goiavier in humid equatorial environment. Journal of Zoology 157:25-45.

Wetterer, A. L., M. V. Rockman, and N. B. Simmons. 2000. Phylogeny of phyllostomid bats (Mammalia: Chiroptera):data from diverse morphological systems, sex chromosomes, and restriction sites. Bulletin of the American Museum of Natural History 248:1-200.

Wheelwright, N. T. 1983. Fruits and the ecology of resplendent quetzals. Auk 100:286-301.

Wible, J. R., AND M. J. NovaceK. 1988. Cranial evidence for the monophyletic origin of bats. American Museum Novitates 2911:1-19.

WiıuG, M. R. 1985. Reproductive patterns of bats from the Caatingas and Cerrado biomes in northeast Brazil. Journal of Mammalogy 66:668-681.

Wisson, D. E. 1973. Reproduction in Neotropical bats. Periodicum Biologorum 75:215217.

Wisson, D. E. 1979. Reproductive patterns. Special Publications, the Museum, Texas Tech University 317-378.

Wilson, D. E., C. O., Handley., JR., and A. L. Gardner. 1991. Reproduction on Barro Colorado Island. Pp. 43-52 in Demography and natural history of the common fruit bat, Artibeus jamaicensis, on Barro Colorado Island, Panama (Handley, C. O., Jr., Wilson, D. E., and A. L. Gardner, eds.). Smithsonian Contributions to Zoology 511, Smithsonian Institution Press. Washington, EE.UU. 
Worthington, A. 1982. Population sizes and breeding rhythms of two species of manakins in relation to food supply. Pp. 213-225 en The ecology of a tropical forest - seasonal rhythms and long-term changes (Leigh, E. G. Jr., Rand, A. S., and D. M. Windsor, eds.). Smithsonian Institution Press. Washington, EE.UU.

Sometido: 17 de diciembre de 2013

Revisado: 4 de marzo de 2014

Aceptado: 22 de marzo de 2014

Editor asociado: Robert Owen

Diseño gráfico editorial: Gerardo Hernández

\section{Appendix: detailed data on female breeding and age structure phenologies}

This appendix provides separate counts for each bat species included in the study, separate counts for females with medium and advanced pregnancies, and counts of females that were detected to be simultaneously pregnant and lactating/postlactating. These counts can be used for verification of our statistical tests, for further statistical analyses, for integration with data from other studies, or as a source of information on the breeding seasonality in particular bat species.

Table A1. Numbers of adult females in five reproductive categories and numbers of individuals in three age categories for nine species of frugivorous bats from cloud forests in the Venezuelan Andes. Data were obtained from 1979 through 2007, and are grouped in 1.5-month intervals. $\mathrm{AF}=$ adult females. $\mathrm{MP}=$ females with medium pregnancies (abdomen moderately distended and rounded owing to the presence of a smaller fetus). AP = females with advanced pregnancies (abdomen markedly distended and irregularly shaped owing to the presence of a larger fetus). LC = lactating females. $\mathrm{PL}=$ postlactating females. $\mathrm{AD}=$ adults. $\mathrm{SA}=$ subadults. $\mathrm{JV}=$ juveniles.

\begin{tabular}{|c|c|c|c|c|c|c|c|c|c|c|c|c|c|c|c|c|}
\hline Bat species & $\mathrm{AF}$ & MP & AP & $\mathrm{LC}$ & $P L$ & $\mathrm{AD}$ & SA & JV & $\mathrm{AF}$ & MP & AP & $\mathrm{LC}$ & PL & $\mathrm{AD}$ & SA & JV \\
\hline & \multicolumn{8}{|c|}{15 January-28 February } & \multicolumn{8}{|c|}{1 March-15 April } \\
\hline Sturnira bidens & 6 & 6 & 0 & 0 & 0 & 8 & 0 & 0 & 2 & 1 & 0 & 1 & 0 & 3 & 0 & 0 \\
\hline Sturnira bogotensis & 7 & 4 & 0 & 0 & 0 & 13 & 0 & 0 & 0 & 0 & 0 & 0 & 0 & 1 & 0 & 0 \\
\hline Sturnira ludovici & 5 & 1 & 1 & 0 & 0 & 7 & 0 & 0 & 3 & 2 & 1 & 0 & 0 & 5 & 0 & 0 \\
\hline Artibeus lituratus & 3 & 1 & 2 & 0 & 0 & 10 & 0 & 0 & 4 & 0 & 2 & 2 & 0 & 11 & 0 & 0 \\
\hline Dermanura bogotensis & 6 & 4 & 0 & 0 & 0 & 9 & 0 & 0 & 8 & 1 & 6 & 1 & 0 & 20 & 0 & 0 \\
\hline
\end{tabular}




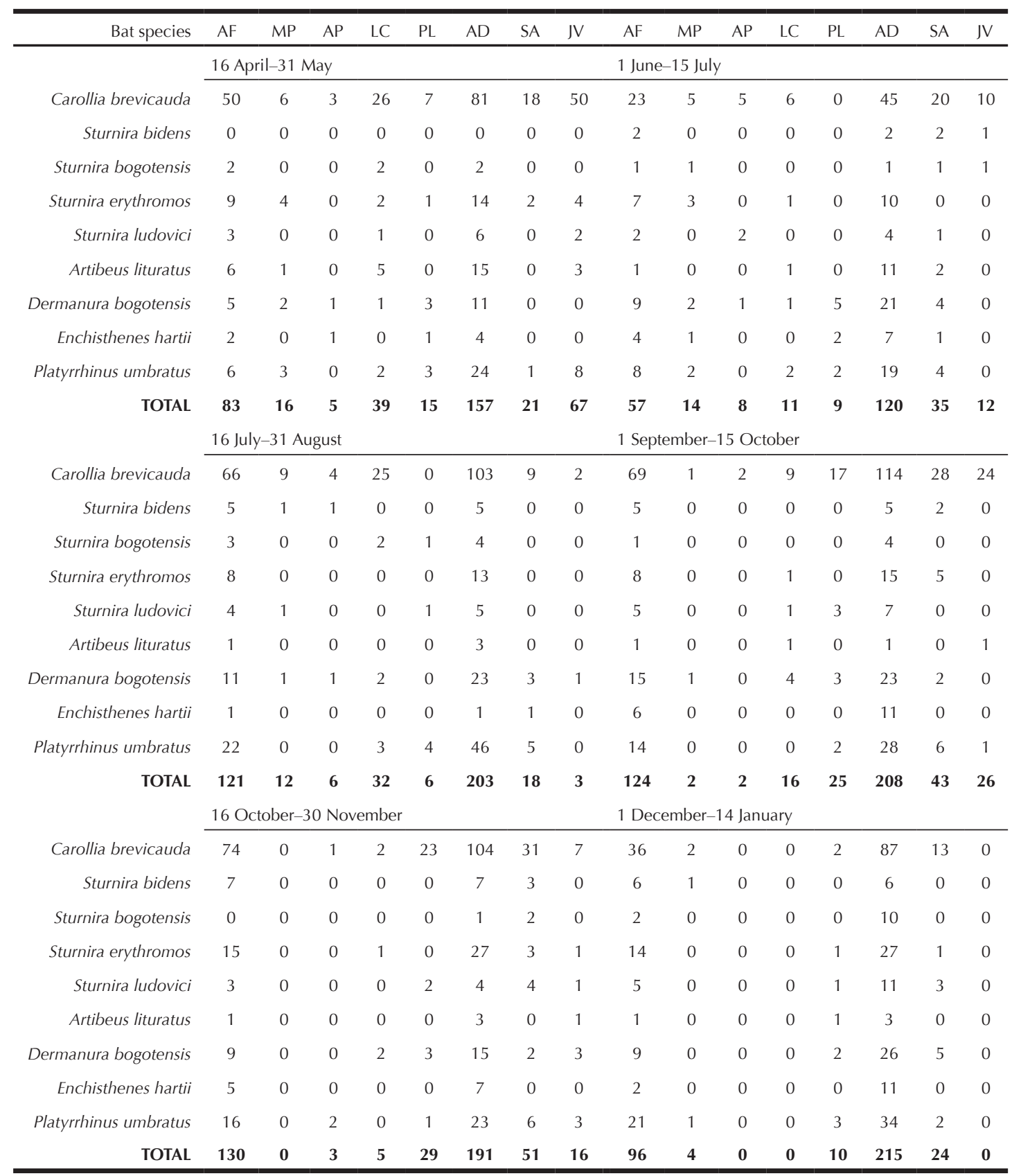

Simultaneously pregnant (medium pregnancy) and lactating females detected in samples were: C. brevicauda, 2 ( 1 June15 July); S. erythromos, 1 (16 April-31 May); A. lituratus, 1 (16 April-31 May); and P. umbratus, 1 (16 April-31 May). Simultaneously pregnant (medium pregnancy) and postlactating females detected in samples were: C. brevicauda, 2 (16 April-31 May); D. bogotensis, 2 (16 April-31 May); E. hartii, 1 (1 June-15 July); and P. umbratus, 3 (1 in 16 April-31 May, 2 in 1 June-15 July). 
